University of Nebraska - Lincoln

DigitalCommons@University of Nebraska - Lincoln

Biochemical acclimation, stomatal limitation and precipitationpatterns underlie decreases in photosynthetic stimulation of soybean(Glycine max) at elevated $\left[\mathrm{CO}_{2}\right]$ and temperatures under fully open airfield conditions

\author{
David M. Rosenthala \\ Ohio University, rosentha@ohio.edu \\ Ursula M. Ruiz-Vera \\ University of Illinois at Urbana-Champaign \\ Matthew H. Siebers \\ University of Illinois at Urbana-Champaign \\ Sharon B. Gray \\ University of Illinois at Urbana-Champaign \\ Carl J. Bernacchi \\ University of Illinois at Urbana-Champaign, USDA Agricultural Research Service, Institute for Genomic \\ Biology
}

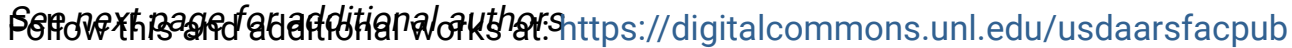

Rosenthala, David M.; Ruiz-Vera, Ursula M.; Siebers, Matthew H.; Gray, Sharon B.; Bernacchi, Carl J.; and Ort, Donald R., "Biochemical acclimation, stomatal limitation and precipitationpatterns underlie decreases in photosynthetic stimulation of soybean(Glycine max) at elevated $\left[\mathrm{CO}_{2}\right]$ and temperatures under fully open airfield conditions" (2014). Publications from USDA-ARS / UNL Faculty. 1477.

https://digitalcommons.unl.edu/usdaarsfacpub/1477

This Article is brought to you for free and open access by the U.S. Department of Agriculture: Agricultural Research Service, Lincoln, Nebraska at DigitalCommons@University of Nebraska - Lincoln. It has been accepted for inclusion in Publications from USDA-ARS / UNL Faculty by an authorized administrator of DigitalCommons@University of Nebraska - Lincoln. 


\section{Authors}

David M. Rosenthala, Ursula M. Ruiz-Vera, Matthew H. Siebers, Sharon B. Gray, Carl J. Bernacchi, and Donald R. Ort 


\title{
Biochemical acclimation, stomatal limitation and precipitation patterns underlie decreases in photosynthetic stimulation of soybean (Glycine max) at elevated $\left[\mathrm{CO}_{2}\right]$ and temperatures under fully open air field conditions
}

\author{
David M. Rosenthal ${ }^{\mathrm{a}}$, Ursula M. Ruiz-Vera ${ }^{\mathrm{b}}$, Matthew H. Siebers ${ }^{\mathrm{b}}$, Sharon B. Gray ${ }^{\mathrm{b}, 1}$, \\ Carl J. Bernacchi ${ }^{\mathrm{b}, \mathrm{c}, \mathrm{d}}$, Donald R. Ort ${ }^{\mathrm{b}, \mathrm{c}, \mathrm{d}, *}$ \\ a Department of Environmental and Plant Biology, Ohio University, Athens, OH 45701, USA \\ ${ }^{\mathrm{b}}$ Department of Plant Biology, University of Illinois at Urbana-Champaign, Urbana, IL 61801, USA

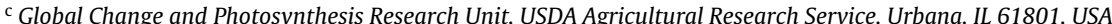 \\ ${ }^{\mathrm{d}}$ Institute for Genomic Biology, University of Illinois at Urbana-Champaign, Urbana, IL 61801, USA
}

\section{A R T I C L E I N F O}

\section{Article history:}

Received 26 February 2014

Received in revised form 10 June 2014

Accepted 13 June 2014

Available online 20 June 2014

\section{Keywords:}

Carboxylation

RuBP regeneration

Stomatal limitation

Photosynthetic nitrogen use efficiency

$V_{c, \max }$

$J_{\max }$

\begin{abstract}
A B S T R A C T
The net effect of elevated $\left[\mathrm{CO}_{2}\right]$ and temperature on photosynthetic acclimation and plant productivity is poorly resolved. We assessed the effects of canopy warming and fully open air $\left[\mathrm{CO}_{2}\right]$ enrichment on (1) the acclimation of two biochemical parameters that frequently limit photosynthesis $(A)$, the maximum carboxylation capacity of Rubisco $\left(V_{c, \max }\right)$ and the maximum potential linear electron flux through photosystem II $\left(J_{\max }\right),(2)$ the associated responses of leaf structural and chemical properties related to $A$, as well as (3) the stomatal limitation $(l)$ imposed on $A$, for soybean over two growing seasons in a conventionally managed agricultural field in Illinois, USA. Acclimation to elevated $\left[\mathrm{CO}_{2}\right]$ was consistent over two growing seasons with respect to $V_{c, \max }$ and $J_{\max }$. However, elevated temperature significantly decreased $J_{\max }$ contributing to lower photosynthetic stimulation by elevated $\mathrm{CO}_{2}$. Large seasonal differences in precipitation altered soil moisture availability modulating the complex effects of elevated temperature and $\mathrm{CO}_{2}$ on biochemical and structural properties related to $A$. Elevated temperature also reduced the benefit of elevated $\left[\mathrm{CO}_{2}\right]$ by eliminating decreases in stomatal limitation at elevated $\left[\mathrm{CO}_{2}\right]$. These results highlight the critical importance of considering multiple environmental factors (i.e. temperature, moisture, $\left[\mathrm{CO}_{2}\right]$ ) when trying to predict plant productivity in the context of climate change.
\end{abstract}

(C) 2014 Elsevier Ireland Ltd. All rights reserved.

\section{Introduction}

It is well known that increases in atmospheric $\mathrm{CO}_{2}$ concentration ( $\left[\mathrm{CO}_{2}\right]$ ) will have direct effects on photosynthesis of $\mathrm{C}_{3}$ plants, particularly in conventional agricultural systems managed to maximize productivity [1]. Rising $\left[\mathrm{CO}_{2}\right]$ and emissions of other more potent greenhouse gases due to anthropogenic activities are likely to increase global mean air temperatures by $\geq 3{ }^{\circ} \mathrm{C}$ before the end of this century [2]. The coupled impact of these changes on carbon assimilation and photosynthetic acclimation in the field is highly

\footnotetext{
* Corresponding author at: Department of Plant Biology, University of Illinois at Urbana-Champaign, Urbana, IL 61801, USA. Tel.: +1 2173332093.

E-mail addresses: rosentha@ohio.edu (D.M. Rosenthal), d-ort@illinois.edu (D.R. Ort).

${ }^{1}$ Current address: University of California, Davis, Davis, CA 95616, USA.
}

uncertain because experiments examining the combined effects of elevated $\left[\mathrm{CO}_{2}\right]$ and temperature have been largely restricted to enclosed chambers [3,4], open top chambers [5] and gradient tunnels [6]. Moreover, the realized benefit of the combined effect of elevated $\left[\mathrm{CO}_{2}\right]$ and temperature on carbon assimilation differs depending on the type of enclosure, as well as the species and the functional types examined as they acclimate in different ways [7]. Taken together, these observations underscore the importance of evaluating and analyzing plant responses to future $\left[\mathrm{CO}_{2}\right]$ and elevated temperature under field conditions.

The rate of photosynthesis of $C_{3}$ plants is most frequently limited or co-limited by two biochemical processes: the maximum in vivo rate of the carboxylation of ribulose bisphosphate (RuBP) by the enzyme RuBP carboxylase/oxygenase (Rubisco; $V_{c, \max }$ ) and/or the maximum potential linear electron flux through photosystem II $\left(J_{\max }\right)$ which is directly linked to the regeneration of RuBP [8]. Both of these processes respond, and may acclimate, to increases in $\left[\mathrm{CO}_{2}\right]$ 
and/or temperature [9]. At atmospheric $\left[\mathrm{CO}_{2}\right]$ of $395 \mathrm{ppm}$, net leaf level photosynthetic carbon assimilation $(A)$ in herbaceous plants is mainly Rubisco-limited [10]. As atmospheric $\left[\mathrm{CO}_{2}\right]$ continues to increase [11], so too will the $\left[\mathrm{CO}_{2}\right]$ at the Rubisco catalytic site thereby stimulating $A$. Rubisco can also catalyze the oxygenation of RuBP leading to the energetically expensive photorespiration process $[12,13]$. Therefore, elevating $\left[\mathrm{CO}_{2}\right]$ will stimulate $A$ both by increasing the velocity of the carboxylation reaction and through competitive suppression of the energetically expensive oxygenation reaction. In contrast, as temperature increases, the kinetics of Rubisco increasingly favor oxygenation of RuBP leading to more photorespiration $[12,13]$. Thus, while elevated $\left[\mathrm{CO}_{2}\right]$ almost always increases rates of photosynthesis [1,14-16], higher temperatures may lead to an increase, decrease, or no change in photosynthesis depending on whether photosynthesis is operating below, at, or above the thermal optimum [17].

Acclimation of $V_{c, \max }$ and $J_{\max }$ to growth at elevated $\left[\mathrm{CO}_{2}\right]$ and warmer temperatures is predicted to alter the response of $A$ in these environments [13]. A relatively consistent reduction of $V_{c, \max }$ in Free Air $\mathrm{CO}_{2}$ Enrichment (FACE) experiments (ca. 13\% on average) has been observed for a range of species $[1,10,18]$, however, since increasing $\left[\mathrm{CO}_{2}\right]$ is also predicted to shift the control of $A$ away from predominately Rubisco-limited and toward predominantly RuBP regeneration-limited control [13,19,20], this down-regulation response of $V_{c, \max }$ has little or no impact on $A$ at the growth $\left[\mathrm{CO}_{2}\right]$ [19]. While $J_{\max }$ has also been shown to down-regulate in plants grown at elevated $\left[\mathrm{CO}_{2}\right]$, it does so to a much lesser extent and not as consistently [21]. Yet, as plants will increasingly be limited by RuBP regeneration as atmospheric $\left[\mathrm{CO}_{2}\right]$ continues to increase small decreases of $J_{\max }$ are likely to represent a proportionally greater limitation on $A$. Should $J_{\max }$ acclimate more than $V_{c, \max }$ to the combined effects of elevated temperature and $\left[\mathrm{CO}_{2}\right]$, then photosynthetic acclimation to elevated temperatures will reduce photosynthetic stimulation by elevated $\mathrm{CO}_{2}$. Because of roles that $V_{c, \max }$ and $J_{\max }$ play in determining photosynthetic rates, it is critical to assess how $V_{c, \max }$ and $J_{\max }$ will acclimate to increases in $\left[\mathrm{CO}_{2}\right]$ and temperature to accurately predict $\mathrm{C}_{3}$ crop productivity in the future [22].

In addition to the biochemical limitations, photosynthetic rate is physically limited by stomatal conductance $\left(g_{s}\right)$ [23], which sets the upper limit on the flux of $\mathrm{CO}_{2}$ into the leaf. Elevated $\mathrm{CO}_{2}$ is well known to decrease $g_{s}$ [14], yet $A$ remains higher at elevated $\mathrm{CO}_{2}$ because of the non-linear relationship between $A$ and the substomatal $\mathrm{CO}_{2}$ concentration $\left(C_{i}\right)$ [23]. Thus stomatal limitation of photosynthesis $(l)$ is lower at elevated $\mathrm{CO}_{2}$ [19]. However, the combined effect of elevated $\mathrm{CO}_{2}$ and temperature on $l$ is uncertain and has never been assessed under field conditions.

In addition to being a model $C_{3}$ species and the world's most important seed legume, soybean, grown in rotation with maize, covers an estimated planting area of 68 million hectares in the United States making it the country's largest single land-use [24]. For these reasons, the effects of combined increases in temperature and $\left[\mathrm{CO}_{2}\right]$ on soybean productivity will have important regional and global implications and, elucidating the responses of key photosynthetic processes to these treatments will carry implications for other $\mathrm{C}_{3}$ species. Using Free Air $\mathrm{CO}_{2}$ Enrichment (FACE) coupled with infrared heating arrays $[25,26]$, we recently showed that soybean yield gains from photosynthetic stimulation by elevated $\mathrm{CO}_{2}$ may be negated by global warming [27]. To elucidate potential ecophysiological mechanisms leading to this lower than expected stimulation, here we (1) assess the degree to which soybean photosynthetic parameters acclimate to elevated temperature and elevated $\left[\mathrm{CO}_{2}\right]$, alone and in combination, under field conditions, (2) determine how photosynthetic parameter acclimation alters $A$ and (3) elucidate the roles stomatal limitation and leaf nitrogen allocation may play in mediating photosynthetic acclimation to elevated $\left[\mathrm{CO}_{2}\right]$ and elevated temperature. Specifically, we hypothesized that (1) $J_{\max }$ would acclimate more to elevated temperature at ambient and elevated $\mathrm{CO}_{2}$ than $V_{c, \max }$ and (2) acclimation to the combined effect of elevated temperature and elevated $\mathrm{CO}_{2}$ would lead to lower photosynthetic stimulation than elevated $\left[\mathrm{CO}_{2}\right]$ alone. The experiment was conducted in 2009 and 2011. These two years differed substantially with respect to ambient temperature and precipitation, the former was cooler and wetter and the latter hotter and drier than the 30 year average [27].

\section{Methods}

\subsection{Site and plots description}

The SoyFACE facility is located in the Experimental Research Station of the University of Illinois at Urbana-Champaign [28]. In 2009 and 2011 eight plots $20 \mathrm{~m}$ in diameter, four that were enriched with pure $\mathrm{CO}_{2}$ from dawn until dusk to a target concentration of the current global mean $\left[\mathrm{CO}_{2}\right]+200 \mu \mathrm{mol} \mathrm{mol}^{-1}$ (585 ppm in 2009 and $590 \mathrm{ppm}$ in 2011) and four that served as controls, were nested at $100 \mathrm{~m}$ spacing within a soybean (Glycine max, Pioneer 93B15) field of ca. 16 ha. Agronomic management practices were typical of corn soybean rotations in this region, so no $\mathrm{N}$ was applied the year of these experiments. However, $\mathrm{N}$ was applied prior to corn plantings in 2008 (160 $\left.\mathrm{kg} \mathrm{ha}^{-1}\right)$ and 2010 (180 $\left.\mathrm{kg} \mathrm{ha}^{-1}\right)$. Ambient atmospheric $\left[\mathrm{CO}_{2}\right]$ for these two growing seasons at SoyFACE were ca. $385 \mathrm{ppm}$ (2009) and $390 \mathrm{ppm}$ (2011). The $\mathrm{CO}_{2}$ enrichment of the four elevated $\left[\mathrm{CO}_{2}\right]$ plots was performed using a modification of the method of Miglietta et al. (2001) described in detail previously [29]. For simplicity, the ambient and elevated $\left[\mathrm{CO}_{2}\right]$ plots are hereafter referred to as 385 and 585.

The canopy temperature of a $7 \mathrm{~m}^{2}$ circular sub-plot within the larger 385 and $585\left[\mathrm{CO}_{2}\right]$ plots was raised by $3.5^{\circ} \mathrm{C}$ using an infrared heating array [27]. Briefly, a ceramic infrared heating array was mounted $1.2 \mathrm{~m}$ above the canopy following the design of Kimball et al. [26] except that the number of heating elements per heater was increased from one to four with a total of six heaters per plot. A proportional-integrative-derivative (PID) feedback control system similar to that assembled by Kimball [25] was designed to maintain the day and night canopy temperature of the warmed plots to $3.5^{\circ} \mathrm{C}$ above that of the corresponding reference plots for the duration of growing season from crop emergence to harvest. The ambient and elevated temperature plots are hereafter referred to as CON and HOT. The experimental treatments were established in a full factorial design with a total of four treatments replicated four times: ambient $\left[\mathrm{CO}_{2}\right]$ at ambient temperature (385-CON); ambient $\left[\mathrm{CO}_{2}\right]$ at $+3.5^{\circ} \mathrm{C}(385-\mathrm{HOT})$; elevated $\left[\mathrm{CO}_{2}\right]$ at ambient temperature (585-CON); elevated $\left[\mathrm{CO}_{2}\right]$ at $+3.5^{\circ} \mathrm{C}(585-\mathrm{HOT})$.

\subsection{Measurement and analysis of photosynthetic sub-stomatal $\left[\mathrm{CO}_{2}\right]$ response ( $\mathrm{A}$ vs. $\mathrm{C}_{i}$ ) curves}

In vivo values of maximum carboxylation capacity $\left(V_{c, \max }\right)$ and maximum linear electron transport through photosystem II $\left(J_{\max }\right)$ were determined from photosynthesis $(A)$ vs. sub-stomatal $\left[\mathrm{CO}_{2}\right]$ $\left(C_{i}\right)$ measurements using an open gas exchange system (LI-6400, LICOR, Lincoln, Nebraska) on six days in 2009 and five days in 2011. Before dawn, the petioles of uppermost fully expanded leaves were cut and immediately submerged in water. Leaves were returned to the lab within $30 \mathrm{~min}$, petioles were recut and kept under water and low light (ca. $<50 \mu \mathrm{mol} \mathrm{m}^{-2} \mathrm{~s}^{-1}$ ). Photosynthesis and conductance of detached soybean leaves collected in this manner are similar to those measured in the field $[19,27,30]$. Fifteen minutes prior to measurements leaves were pretreated to high light (ca. $1000 \mu \mathrm{mol} \mathrm{m}^{-2} \mathrm{~s}^{-1}$ ). Leaves were then placed in the measurement 
cuvette and allowed to reach steady state photosynthesis at their growth $\left[\mathrm{CO}_{2}\right]$ (i.e. $385 \mathrm{ppm}$ or $585 \mathrm{ppm}\left[\mathrm{CO}_{2}\right]$ ) at a saturating light level of $1500 \mu \mathrm{mol} \mathrm{m}^{-2} \mathrm{~s}^{-1}$. The petioles of all leaves remained submerged in water throughout the measurements. The mean leaf temperature $\left(T_{l},{ }^{\circ} \mathrm{C}\right)$ and vapor pressure deficit determined based on $T_{l}$ (VpdL; kPa) for the $A$ vs. $C_{i}$ curves was $25 \pm 0.9{ }^{\circ} \mathrm{C}$ and $1.39 \pm 0.25 \mathrm{kPa}$ (s.d.) for $n=212 \mathrm{~A}$ vs. $C_{i}$ curves in 2009. Similarly, mean VpdL was $1.17 \pm 0.18 \mathrm{kPa}$ and leaf temperature was $25.4 \pm 0.7^{\circ} \mathrm{C}$ for $n=219 \mathrm{~A}$ vs. $C_{i}$ curves in 2011 . Once steady state $A$ was reached, measurements of photosynthesis, $C_{i}$, and operating efficiency of photosystem II ( $\Phi_{P S I}$; Supplemental Figure 1 ) were recorded at the growth $\left[\mathrm{CO}_{2}\right] ;\left[\mathrm{CO}_{2}\right]$ was then decreased stepwise to $50 \mu \mathrm{mol} \mathrm{mol}^{-1}$, increased again to the growth $\left[\mathrm{CO}_{2}\right]$, and then increased stepwise to $1500 \mathrm{ppm}\left[\mathrm{CO}_{2}\right]$. A minimum of 11 data points were collected for each leaf and the $A$ vs. $C_{i}$ data were fitted to the biochemical model of photosynthesis [31] and solved for $V_{c, \max }$, $J_{\max }$ and $R_{d}$, following the methods outlined by Long and Bernacchi [32].

\subsection{Leaf $N$ and structural traits}

Two leaf disks were collected from upper canopy leaves of 3-5 plants in each plot on 6 days in 2009 and 6 days in 2011. Leaf disks were dried at $60^{\circ} \mathrm{C}$ for $48 \mathrm{~h}$ and weighed to determine leaf mass per area $\left(L M A, \mathrm{~g} \mathrm{~m}^{-2}\right)$, Leaf $\mathrm{N}$ per area $\left(N_{\text {area }} ; \mathrm{g} \mathrm{m}^{-2}\right)$ and $\mathrm{N}$ percentage per unit mass $\left(N_{\text {mass }} ; \%\right)$. Disks were ground to a fine powder and nitrogen $(\mathrm{N})$ content was determined by total combustion (Costech ECS 4010, Valencia, CA, USA). Leaf disks were collected at the same time as field measurement of gas exchange reported in [27], therefore photosynthetic nitrogen use efficiency (PNUE; $\mu \mathrm{mol} \mathrm{CO} \mathrm{Cm}^{-2} \mathrm{~s}^{-1}$ ) was estimated using these leaf $\mathrm{N}$ estimates and measurements of $A$ reported in [27].

\subsection{Stomatal limitation}

Stomatal limitation ( $l$ ) of $A$ is an estimate of the proportion by which actual stomatal conductance $\left(g_{s}\right)$ decreases $A$ relative to what $A$ would be assuming infinite conductance between the atmosphere and the leaf sub-stomatal airspace $\left(A^{0}\right)$ and is usually estimated from $A$ vs. $C_{i}$ curves using the following relationship [23]:

$l=1-\left(\frac{A}{A^{0}}\right)$

$A$ is the rate of carbon assimilation at the measurement $\left[\mathrm{CO}_{2}\right]$ and based on the actual $g_{s}$ and $A^{0}$ is photosynthesis assuming infinite $g_{s}$ (i.e. when $C_{i}=$ atmospheric $\left[\mathrm{CO}_{2}\right]$ ).

Stomatal limitation for this study is referred to as the "field" stomatal limitation ( $l_{-}$field) and was calculated using $A$ and $C_{i}$ measured in the field reported in Ruiz-Vera et al. [27] coupled with modeled estimates of $A^{0}$. Modeled values of $A^{0}$ were calculated with the Farquhar et al. [33] photosynthesis model by using the laboratory determinations of $V_{c, \max @ 25}$ and $J_{\max @ 25}$ corrected for field light $(Q)$ and temperature $\left(T_{l}\right)$ conditions (i.e. from Ruiz-Vera et al. [27]). Stomatal limitation was calculated in this way to resolve treatment effects on stomatal limitation from diurnal changes in biochemical limitations to photosynthesis.

\subsection{Temperature response curves}

The response of leaf photosynthesis to temperature was measured on leaves collected predawn at three different phenological stages during the 2009 growth season (July 6-7, vegetative; August $3-4$, beginning pod; August 17-18, beginning seed). Temperature response curves were not measured in 2011. Photosynthesis was measured using a gas exchange system (LI-6400; LI-COR Inc., Lincoln, Nebraska) at a saturating light level of $1500 \mu \mathrm{mol} \mathrm{m}^{-2} \mathrm{~s}^{-1}$ and at $\left[\mathrm{CO}_{2}\right]$ of $385.8 \pm 7$ (s.d.) $\mu \mathrm{mol} \mathrm{mol}{ }^{-1}$ for ambient or $583.1 \pm 8.5$ (s.d.) $\mu \mathrm{mol} \mathrm{mol}{ }^{-1}$ for elevated $\left[\mathrm{CO}_{2}\right]$ grown plants. Leaf vapor pressure deficit (VpdL; $\mathrm{kPa}$ ) ranged from 0.77 at $20^{\circ} \mathrm{C}$ to 3.12 at $38^{\circ} \mathrm{C}$ with a mean VpdL for all measurements of $1.7 \pm 0.45$ (s.d.). At each temperature, leaves were monitored until the target temperature and steady state $A$ was reached based on the measured coefficient of variation of the gas exchange system falling below $1 \%$; this took approximately 8-10 min for each stepwise change in temperature. Each temperature response curve took slightly longer than $60 \mathrm{~min}$ to complete after the leaf reached steady-state and the gas exchange system stabilized. Following the measurement at $38^{\circ} \mathrm{C}$, leaves were allowed to cool and were measured again at $29^{\circ} \mathrm{C}$ to ensure that any decrease in $A$ above the optimum was reversible and not due to permanent damage to the photosynthetic apparatus.

\subsection{Statistical analysis}

The seasonal responses of parameters to growth at elevated temperature and elevated $\left[\mathrm{CO}_{2}\right]$ were analyzed separately for each year using a mixed model repeated measures analysis of variance (PROC mixed, SAS). Temperature (Temp), $\left[\mathrm{CO}_{2}\right]$, day of year (DOY) and year $(2009,2011)$ were treated as fixed effects and block was a random effect. Seasonal or pre-senescence means are averages of all the plots for a given treatment for the specified time period. Significant differences between seasonal least square means were detected using post hoc tests adjusted for multiple comparisons. As there were only four blocks, significant probability was set a priori at $p<0.1$ to reduce the likelihood of type II errors [34,35].

\section{Results}

\subsection{Soil moisture depletion profiles differed by treatment and year}

At planting, soil volumetric water content (VWC; \% v) for the upper most soil layer (upper; 0-20 cm) was similar in 2009 (DOY 160) and 2011 (DOY 159) with upper soil at field capacity in 2009 (ca. 41\%) and slightly lower than field capacity in 2011 (ca. 35\%) (Fig. 1). However, seasonally averaged VWC was higher in 2009 than 2011 because precipitation consistently replenished soil moisture and returned VWC to near field capacity several times during the 2009 growing season.

The response of VWC to treatments differed between years. In 2009, VWC was lower in HOT plots when compared to CON plots and lower in 385 plots compared to 585 plots for the upper and middle $(30-50 \mathrm{~cm})$ soil layers. By contrast in 2011 , VWC was only detectably lower in the upper soil layer in HOT plots and there were no detectable differences of VWC in 385 vs. 585 plots. However, in both years there was a significant $\mathrm{CO}_{2} \times$ temperature interaction effect for soil moisture in the middle soil layer because soil moisture was more depleted in 385-HOT than in 585-HOT when compared to the $385-\mathrm{CON}$ and $585-\mathrm{CON}$ plots, respectively (Table 1 ).

\subsection{The responses of $V_{c, \max }$ to elevated $\mathrm{CO}_{2}$ and $J_{\max }$ to elevated temperature were consistent between years}

Both $V_{c, \max @ 25}$ and $J_{\max @ 25}$ responded to temperature and $\left[\mathrm{CO}_{2}\right]$ dynamically within years but the overall trends were similar between years (Fig. 2). There was no significant interactive effects of elevated temperature and elevated $\left[\mathrm{CO}_{2}\right]$ for either parameter in either year (Table 2). There was, however, a statistically significant main effect for $V_{c, \max 25}$, which was consistently lower at elevated $\left[\mathrm{CO}_{2}\right]$ (i.e. $-13.6 \pm 1.4 \%$ in $585-\mathrm{CON}$ and $-11.8 \pm 1.4 \%$ in 585-HOT), and for $J_{\max @ 25}$, which was consistently lower at 


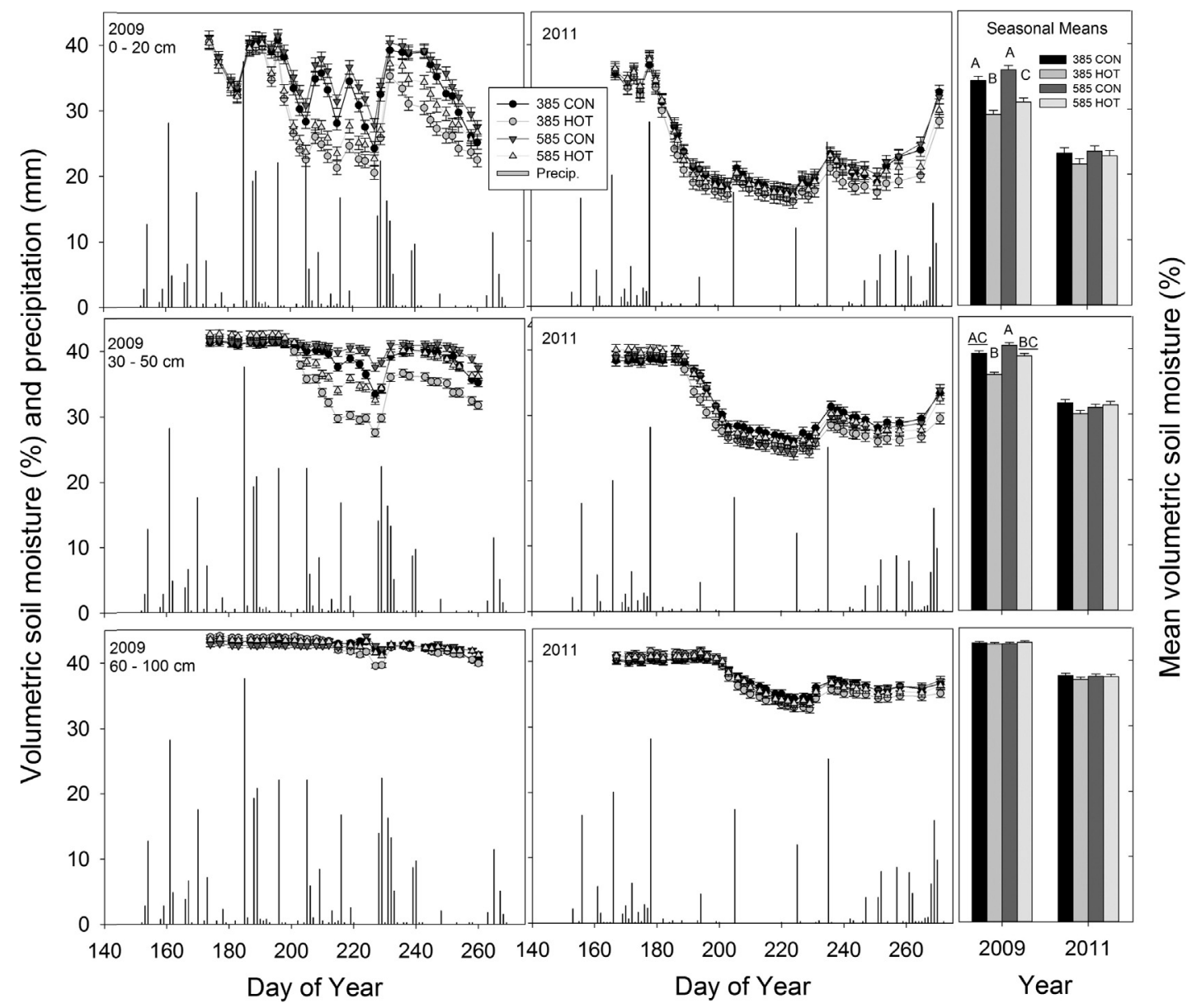

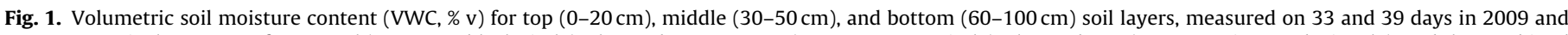

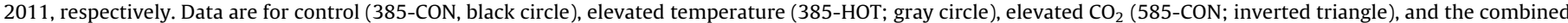

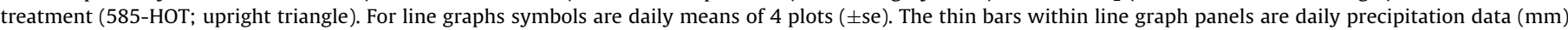

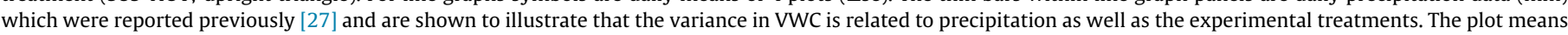

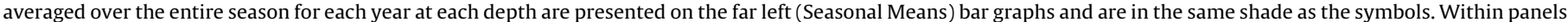
bars with different letters are significantly different.

elevated temperature (i.e. $-7.8 \pm 0.4 \%$ in 385 -HOT and $-10.7 \pm 1.8 \%$ in 585-HOT) (Table 2). As a result of the contrasting responses of $V_{c, \text { max@25 }}$ and $J_{\max @ 25}$ to temperature and $\mathrm{CO}_{2}$, the ratio of $V_{c, \max @ 25}$ to J $\operatorname{max@25}\left(V_{c, \max 25} / J_{\max @ 25}\right)$ was increased by temperature (i.e. $9.6 \pm 0.2 \%$ in 385 -HOT and $9.0 \pm 2.7 \%$ in 585-HOT) and decreased by elevated $\left[\mathrm{CO}_{2}\right]$ in both years. Because the 585-HOT treatment response is similar to the $585-\mathrm{CON}$ treatment with regards to $V_{c, \max 25}$ and similar to the 385-HOT treatment with regards to $J_{\max @ 25}$ the $V_{c, \max @ 25} / J_{\max @ 25}$ ratio in 585-HOT was indistinguishable from $385-\mathrm{CON}$.
To resolve the differences in biochemical acclimation due to treatments from those that included monocarpic senescence caused by translocation of resources from leaves to pods [36] we removed the last days in 2009 and 2011 from the analysis (see Fig. 2, vertical dashed line) and compared the mean response. The latter analyses revealed that prior to senescence in 2009, $V_{c, \text { max@25 }}$ was actually significantly higher in HOT compared to CON plots $\left(F_{1,12.6}=5.24, p<0.05\right)$ and $J_{\max @ 25}$ was only detectably lower in 585-HOT when compared to 385-CON. In 2011, the acclimation patterns were similar pre and post senescence.

Table 1

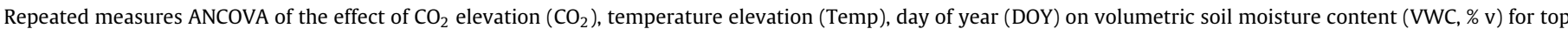

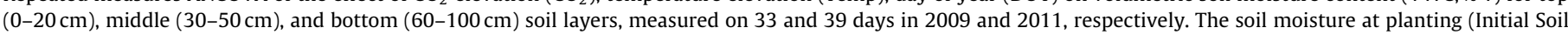
Moisture) is included as covariate to account for soil moisture differences across plots at planting.

\begin{tabular}{|c|c|c|c|c|c|c|c|c|}
\hline & \multicolumn{8}{|c|}{ Main effects and interactions } \\
\hline & $\mathrm{CO}_{2}$ & Temp & Temp $\times \mathrm{CO}_{2}$ & DOY & $\mathrm{DOY} \times \mathrm{CO}_{2}$ & DOY $\times$ Temp & $\mathrm{DOY} \times \mathrm{CO}_{2} \times \mathrm{Temp}$ & Initial Soil Moisture \\
\hline \multicolumn{9}{|l|}{2009} \\
\hline Top $(0-20)$ & 0.0008 & $<0.0001$ & ns & $<0.0001$ & ns & $<0.0001$ & ns & 0.037 \\
\hline Middle (30-50) & 0.0001 & $<0.0001$ & 0.0466 & $<0.0001$ & $<0.0001$ & $<0.0001$ & ns & ns \\
\hline Bottom (60-100) & ns & ns & ns & $<0.0001$ & 0.0052 & $<0.0001$ & ns & 0.0069 \\
\hline \multicolumn{9}{|l|}{2011} \\
\hline Top $(0-20)$ & ns & 0.0513 & ns & $<0.0001$ & ns & 0.0089 & 0.0442 & 0.008 \\
\hline Middle (30-50) & ns & ns & 0.0179 & $<0.0001$ & ns & 0.0002 & ns & ns \\
\hline Bottom (60-100) & ns & ns & ns & $<0.0001$ & ns & ns & ns & ns \\
\hline
\end{tabular}




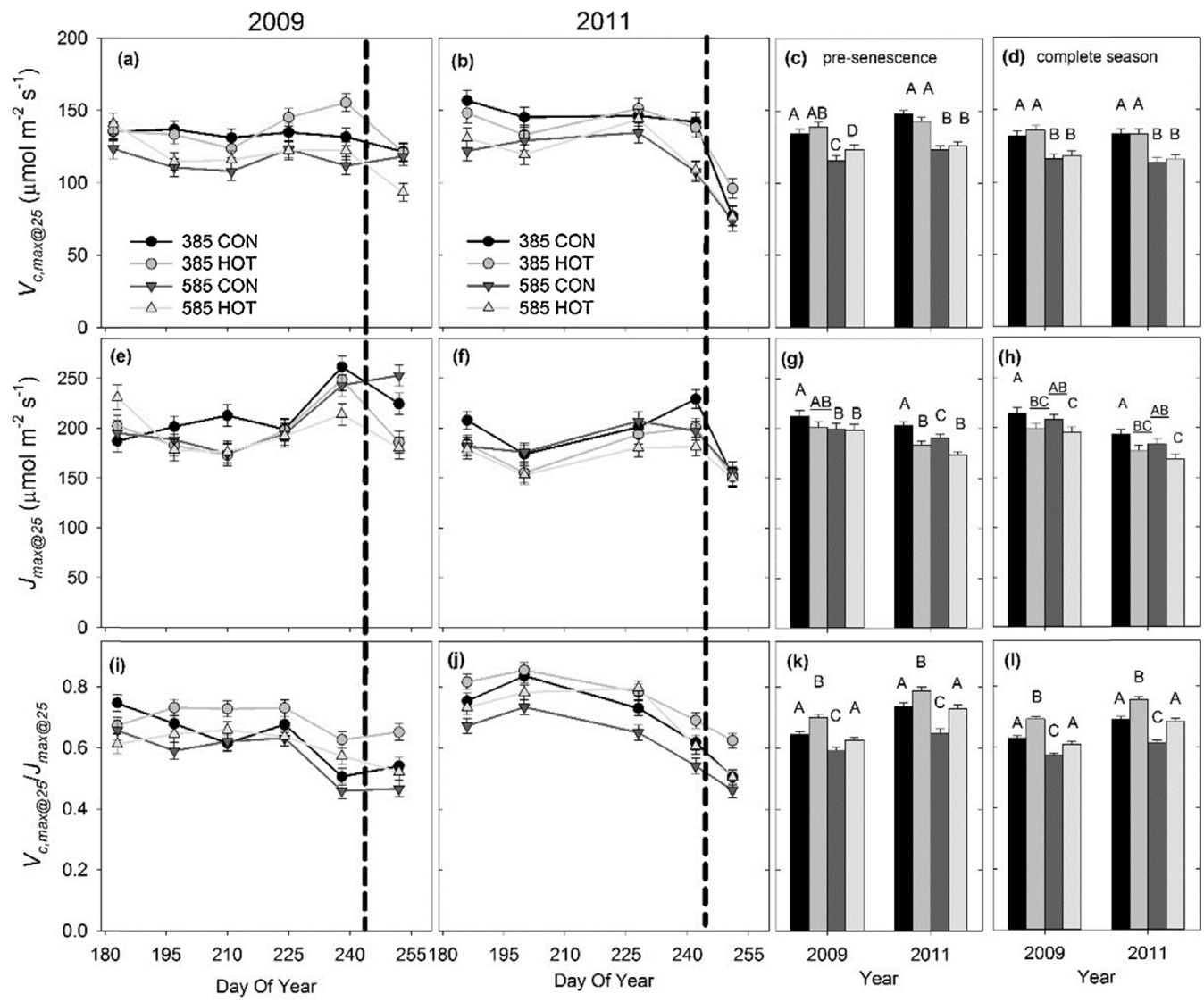

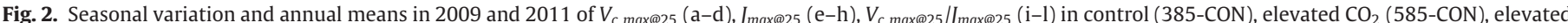

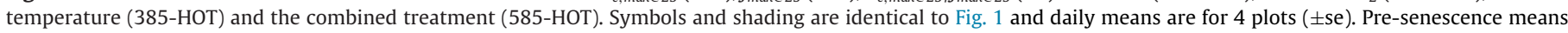

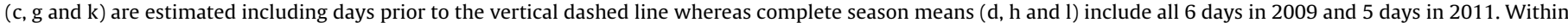
panels bars with different letters are significantly different.

Table 2

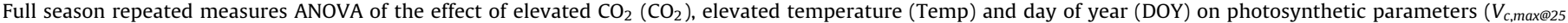

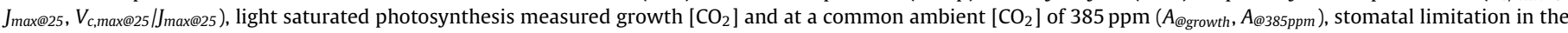

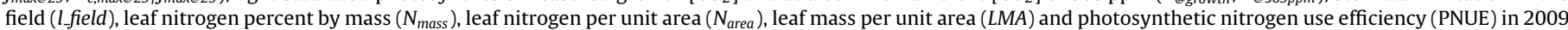
and 2011.

\begin{tabular}{|c|c|c|c|c|c|c|c|}
\hline & \multicolumn{7}{|c|}{ Main effects and interactions } \\
\hline & $\mathrm{CO}_{2}$ & Temp & Temp $\times \mathrm{CO}_{2}$ & DOY & $\mathrm{DOY} \times \mathrm{CO}_{2}$ & DOY $\times$ Temp & $\overline{\mathrm{DOY} \times \mathrm{CO}_{2} \times \mathrm{Temp}}$ \\
\hline \multicolumn{8}{|l|}{2009} \\
\hline$V_{c, \max @ 25}$ & $<0.0001$ & ns & ns & $<0.0001$ & ns & $<0.0001$ & 0.0027 \\
\hline$J_{\max @ 25}$ & 0.0395 & $<0.0001$ & ns & $<0.0001$ & 0.0605 & $<0.0001$ & ns \\
\hline$V_{c, \max } @ 25 / J_{\max @ 25}$ & $<0.0001$ & $<0.0001$ & ns & $<0.0001$ & ns & 0.0008 & ns \\
\hline$A_{@ g r o w t h}$ & 0.0025 & 0.0216 & ns & $<0.0001$ & ns & $<0.0001$ & ns \\
\hline$A_{@ 385 p m}$ & $<0.0001$ & ns & 0.0683 & $<0.0001$ & ns & $<0.0001$ & ns \\
\hline l_field & 0.0015 & $<0.0001$ & ns & $<0.0001$ & ns & $<0.0001$ & ns \\
\hline$N_{\text {mass }}$ & $<0.0001$ & ns & 0.0967 & $<0.0001$ & 0.0083 & $<0.0001$ & 0.0366 \\
\hline$N_{\text {area }}$ & 0.0156 & 0.0799 & ns & $<0.0001$ & ns & $<0.0001$ & ns \\
\hline LMA & $<0.0001$ & 0.016 & ns & $<0.0001$ & 0.0071 & 0.0253 & ns \\
\hline PNUE $^{a}$ & 0.0002 & ns & ns & $<0.0001$ & ns & 0.0098 & ns \\
\hline \multicolumn{8}{|l|}{2011} \\
\hline$V_{c, \max @ 25}$ & $<0.0001$ & ns & ns & $<0.0001$ & 0.0913 & ns & ns \\
\hline$J_{\max @ 25}$ & ns & 0.0074 & ns & $<0.0001$ & ns & ns & ns \\
\hline$V_{c, \max @ 25} / J_{\max @ 25}$ & $<0.0001$ & $<0.0001$ & ns & $<0.0001$ & ns & ns & ns \\
\hline$A_{@ g r o w t h}$ & 0.0014 & 0.0134 & ns & $<0.0001$ & ns & $\mathrm{ns}$ & ns \\
\hline$A_{@ 385 p p m}$ & 0.0148 & 0.0275 & ns & $<0.0001$ & ns & ns & ns \\
\hline lffield & 0.0067 & $<0.0001$ & 0.035 & $<0.0001$ & 0.0304 & 0.0093 & 0.0222 \\
\hline$N_{\text {mass }}$ & $<0.0001$ & ns & 0.0653 & $<0.0001$ & 0.0007 & ns & 0.0771 \\
\hline$N_{\text {area }}$ & 0.0452 & 0.0278 & ns & 0.0002 & 0.0493 & 0.0317 & ns \\
\hline LMA & $<0.0001$ & 0.0015 & 0.0705 & $<0.0001$ & ns & ns & ns \\
\hline PNUE $^{a}$ & $<0.0001$ & 0.0082 & ns & $<0.0001$ & ns & 0.0023 & ns \\
\hline
\end{tabular}

a PNUE was estimated with using $N_{\text {area }}$ reported here and measurements of $A$ reported by [27]. See methods for details. 


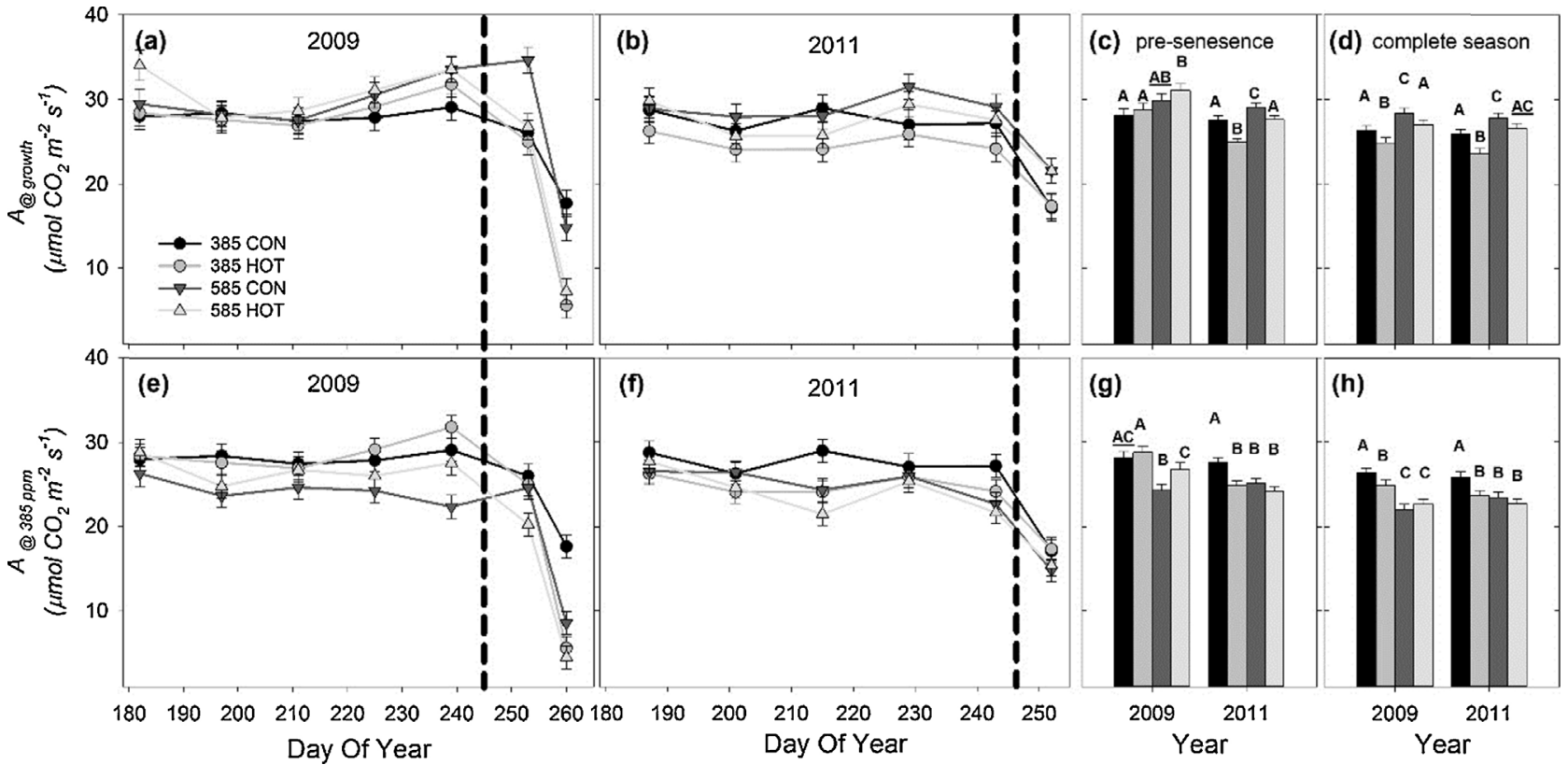

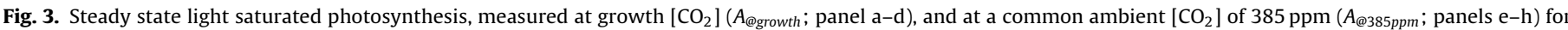

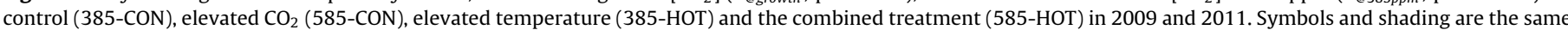

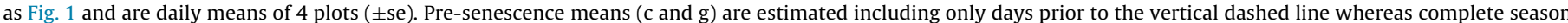
means ( $\mathrm{d}$ and $\mathrm{h}$ ) are for 7 days in 2009 and 6 days in 2011. Within years and panels bars with different letters are significantly different.

\subsection{Acclimation to temperature ameliorated biochemical acclimation of $\mathrm{A}$ to elevated $\mathrm{CO}_{2}$ in 2009 but not 2011}

Light saturated steady state photosynthesis rates at growth $\left[\mathrm{CO}_{2}\right]$ ( $\left.A_{@ \text { growth }}\right)$ and at a common ambient $\mathrm{CO}_{2}$ of $385 \mathrm{ppm}$

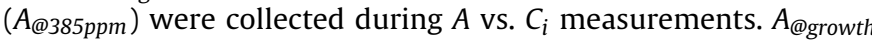
was greater in 585-CON and 585-HOT when compared to ambient $\mathrm{CO}_{2}$ controls (Fig. $3 \mathrm{~d}$ ) but $A_{@ g r o w t h}$ was significantly lower in $385-\mathrm{HOT}$ and 585-HOT when compared to 385-CON and 585-CON respectively (Fig. 3d). When measured at a common ambient $\mathrm{CO}_{2}$ of 385 ppm ( $A_{@ 385 p p m}$, Fig. 3e-h), photosynthetic rates of 585-CON and 585-HOT plots were significantly lower than 385-CON and 385HOT plots, respectively, in 2009 and 2011 (Table 2), consistent with photosynthetic acclimation to growth at elevated $\mathrm{CO}_{2}$ (Fig. $3 \mathrm{~h}$ ).

As above, we resolved the differences in $A$ due to treatments from those potentially related to senescence by removing two days in 2009 and 1 day in 2011 from the analysis of the response of $A_{@ g r o w t h}$ to $\mathrm{CO}_{2}$ and temperature (Fig. $3 \mathrm{c}$ and $\mathrm{g}$ ). This latter analysis showed that $A_{@ g r o w t h}$ remained significantly lower in HOT plots in $2011\left(F_{1,11.5}=16.81, p<0.01\right)$. In contrast, in $2009 A_{@ 385 p p m}$ was significantly higher in 585-HOT compared to $585-\mathrm{CON}$, following post hoc tests (Fig. $3 \mathrm{~g}$ ). Measured values of $A_{@ g r o w t h}$ (above) and $g_{\text {s@growth }}$ (Supplemental Figure 2) were consistent with $A$ and $g_{s}$ rates measured on this cultivar in the field $[19,28,37]$ indicating that predawn excision did not detectably alter leaf photosynthesis.

\subsection{Elevated temperature eliminated the benefit of elevated $\mathrm{CO}_{2}$ for stomatal limitation in both years and stomatal limitation was greater in 2011 than in 2009}

While elevating $\mathrm{CO}_{2}$ decreased stomatal limitation in the field ( $l_{\text {ffield }}$ ) by similar amounts $(-13.7 \pm 0.6 \%)$ in both years (Table 2 and Fig. 4) elevating temperature increased $l_{\text {field }}$ by $40.7 \pm 2.5 \%$ in 2009 and by $55.4 \pm 6.5 \%$ in 2011 in the HOT treatments plots relative to the controls. Stomatal limitation was always greatest in 385-HOT plots and the $\mathrm{CO}_{2} \times$ temperature $\times$ time interaction was statistically significant (Table 2 ) in 2011 because stomatal limitation increased more rapidly over time in 385-HOT than in any other plot. Consequently, lfield was nearly two-fold greater in 385-HOT plots when compared with other plots at the middle and end of August in 2011 (i.e. DOY 228 and 243) (Fig. 4).

3.5. Elevating temperature had the opposite effect of elevated $\left[\mathrm{CO}_{2}\right]$ on leaf structure, nitrogen allocation and photosynthetic nitrogen use efficiency

Season mean total leaf nitrogen content $\left(N_{\text {mass }}\right.$; \%) for both years was $19 \pm 0.2 \%$ lower in 585 -CON and $16.8 \pm 1.6 \%$ lower in 585 -HOT when compared to 385-CON plots (Table 2 and Fig. 5). A significant $\mathrm{CO}_{2} \times$ temperature interaction with respect to $N_{\text {mass }}$ in both years indicates that elevated temperature consistently lowered $N_{\text {mass }}$ in 385 plots but increased $N_{\text {mass }}$ in 585 plots. The significant three way interaction of DOY $\times\left[\mathrm{CO}_{2}\right] \times$ Temp in both years is the result of differences in the timing of peak levels of $N_{\text {mass }}$. The three way interaction was particularly evident in 2009 where, for instance, $N_{\text {mass }}$ peaks are at different times for 385-CON and 385-HOT whereas in 2011 the peaks differ for 585-CON and 585-HOT (Fig. 5a, b and d).

In 2009, when averaged over the whole season, elevated $\mathrm{CO}_{2}$ decreased nitrogen allocation per unit area $\left(N_{\text {area }}, \mathrm{g} \mathrm{m}^{-2}\right)$ by $6.5 \%$ and elevated temperature decreased $N_{\text {area }}$ by $4.8 \%$ and $2.5 \%$ in $385-$ HOT and 585-HOT plots, respectively (Table 2 and Fig. 5e and h). The combined effects of elevated $\left[\mathrm{CO}_{2}\right]$ and temperature were additive in 2009 , as $N_{\text {area }}$ was $8.9 \%$ lower in 585-HOT when compared to ambient unheated plots. Increasing temperature also caused $N_{\text {area }}$ to increase faster early in the season and decrease faster late in the season when compared to unheated plots in the 2009 season. In 2011, elevated $\left[\mathrm{CO}_{2}\right]$ decreased $N_{\text {area }}$ by $4.8 \%$ (Fig. $5 \mathrm{f}$ and h); elevated temperature decreased $N_{\text {area }}$ by similar amounts in 385-HOT and 585 -HOT plots (ca. $5 \%$ ) and $N_{\text {area }}$ was $9.6 \%$ lower in $585-$ HOT when compared to control. Thus the main effects of elevated $\mathrm{CO}_{2}$ and temperature were also additive with respect to $N_{\text {area }}$ in 2011.

Removing two days in 2009 from the analysis of $N_{\text {area }}$ and $N_{\text {mass }}$ to resolve the differences due to treatments from those potentially related to senescence, we see that temperature had the opposite effect to that of the full season trend. That is, this analysis revealed that in the HOT plots there were significant increases in 


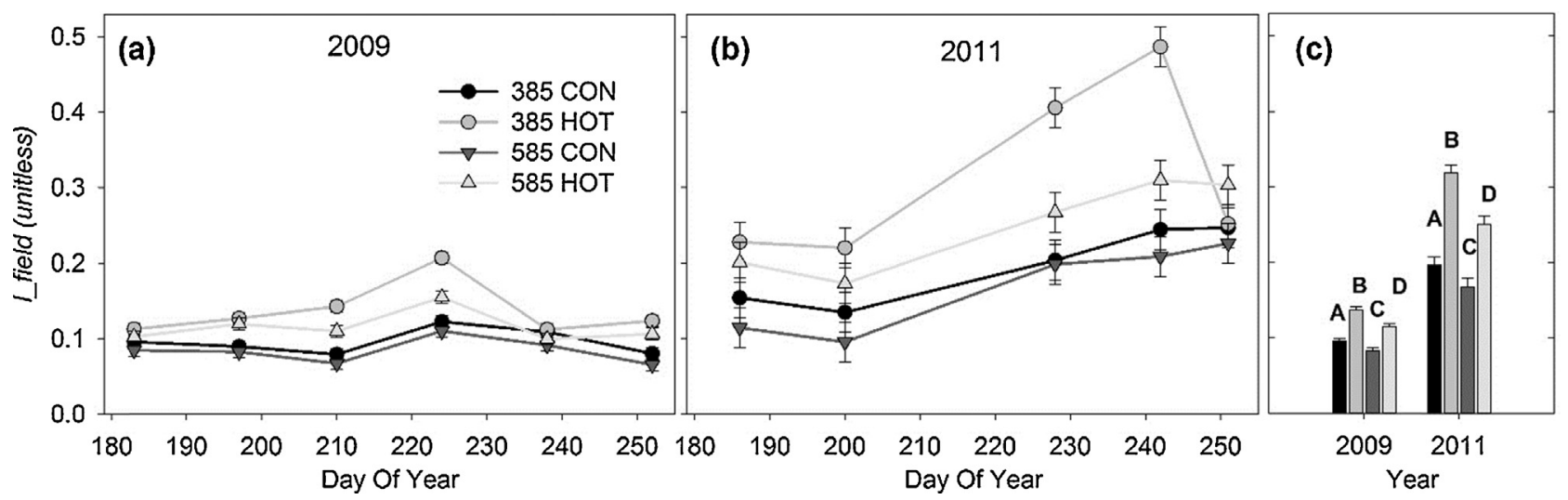

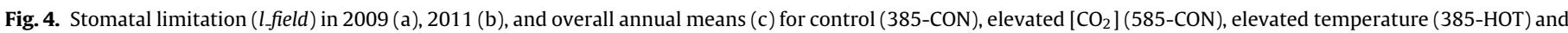

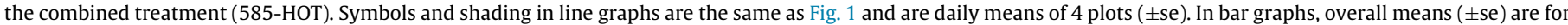
6 days in 2009 and 5 days in 2011. Within years bars with different letters are significantly different.

$N_{\text {mass }}\left(F_{1,12}=28.87, p<0.001\right)$ and $N_{\text {area }}\left(F_{1,12}=4.04, p<0.07\right)$ prior to senescence in 2009. Unfortunately, such as comparison is not possible for 2011 as there were no late season $N_{\text {area }}$ data.

Elevated $\mathrm{CO}_{2}$ increased leaf mass per unit area $\left(L M A, \mathrm{~g} \mathrm{~m}^{-2}\right)$ by $15 \%$ in 2009 and by $18.9 \%$ in 2011 . Averaged over all treatments, elevated temperature decreased $L M A$ by about $5.7 \%$ when compared to 385-CON; post hoc test show that LMA was significantly lower in 585 -HOT plots when compared to 585-CON in both years (Table 1 and Fig. 51) with $L M A$ decreasing twice as much due to temperature in 2011 (i.e. $-9.9 \%$ ) than in 2009 (-5\%). Removing two days in 2009 from the analysis of $L M A$ revealed a similar response to elevated $\mathrm{CO}_{2}$ but the effect of temperature was not detectable.

Photosynthetic nitrogen use efficiency (PNUE) was significantly higher in elevated $\mathrm{CO}_{2}$ increasing by $16 \%$ in 2009 and $26 \%$ in 2011 when compared to 385-CON (Table 2; Supplemental Figure 3). Temperature elevation affected PNUE differently between years. In 2009 only 385-HOT had significantly lower (-10\%) PNUE than 385-CON whereas in 2011 PNUE was lower in 385-HOT (-11\%) and $585-\mathrm{HOT}(-8 \%)$ when compared to $385-\mathrm{CON}$ and $585-\mathrm{CON}$, respectively. The effects of elevated temperature and $\left[\mathrm{CO}_{2}\right]$ were similar

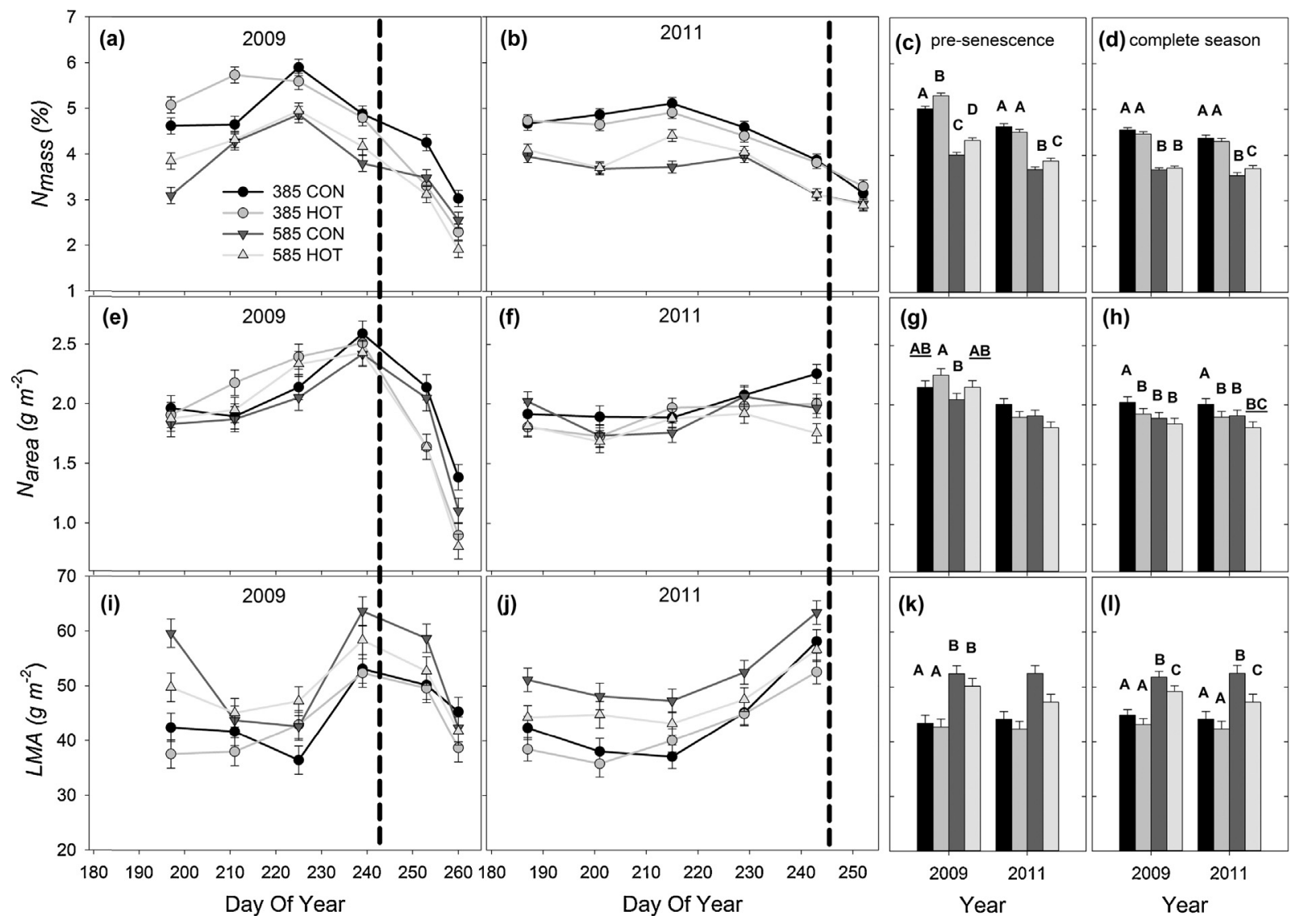

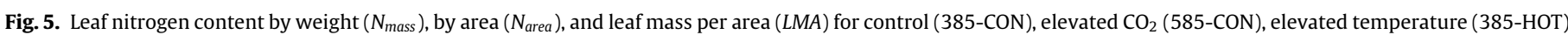

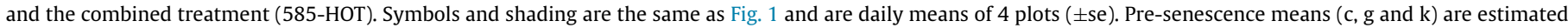

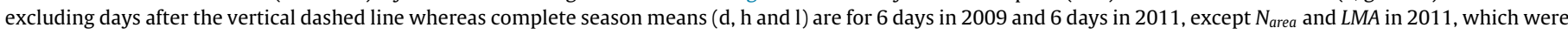
analyzed for 5 days. Within years bars with different letters are significantly different. 
both prior to senescence and for the whole season (Supplemental Figure 3).

\subsection{Synergistic effect of elevated $\mathrm{CO}_{2}$ and temperature on the thermal response of $A$ is transient}

The response of $A_{@ g r o w t h}$ to leaf temperature $\left(T_{l}\right)$ was measured in the laboratory on three days in 2009 for all four treatments (Fig. 6). The synergistic effect of elevated $\left[\mathrm{CO}_{2}\right]$ and elevated temperature on the thermal response of $A$ (i.e. $A$ is significantly more stimulated in 585-HOT than 585-CON) was only evident during vegetative growth at 30 and $35^{\circ} \mathrm{C}$ (Fig. 6a).

\section{Discussion}

The goals of this experiment were to quantify photosynthetic acclimation in soybean subjected to growth at elevated $\left[\mathrm{CO}_{2}\right]$ and elevated temperature, singly and in combination, under field conditions. We build on the recently published results of Ruiz-Vera et al. [27], by elucidating some of the key ecophysiological and associated biochemical mechanisms underlying the negation of $\mathrm{CO}_{2}$ stimulation of assimilation by elevated temperature reported earlier. Because precipitation substantially altered field conditions between the two years, we assessed how changes in soil moisture may have modulated acclimation responses to elevated temperature and $\mathrm{CO}_{2}$. The data fully supported our first hypothesis that $J_{\max @ 25}$ would acclimate more to elevated temperature, regardless of [ $\left.\mathrm{CO}_{2}\right]$, than would $V_{c, \max @ 25}$. Moreover, the substantial acclimation of $J_{\max @ 25}$ likely reduced some of the purported synergistic effects of increases in temperature at elevated $\left[\mathrm{CO}_{2}\right][27,38,39]$. The data only partially supported our second hypothesis; that is, the combined effect of elevated temperature and elevated $\left[\mathrm{CO}_{2}\right]$ did not always lower photosynthetic stimulation when compared to the effect of elevated $\left[\mathrm{CO}_{2}\right]$ alone. While biochemical acclimation to elevated $\mathrm{CO}_{2}$ was similar between years, acclimation to temperature, and its effect on assimilation, differed substantially between years.

Higher soil moisture in 2009 ameliorated the detrimental effects of temperature whereas warmer ambient temperatures and low soil moisture likely interacted to exacerbate the effect of chronic temperature elevation in 2011. In spite of plentiful precipitation in 2009, VWC profiles revealed that moisture depletion was greater at depth in HOT plots compared to CON plots. Plants in HOT plots apparently accessed moisture deeper in the soil than plants in CON plots, probably because soybeans in HOT plots were rooted more deeply. Nevertheless, soil VWC was lower in the HOT plots throughout the soil profile in 2009 (Fig. 1), consistent with greater moisture demand and lower midday water potential in HOT plots [27].

By contrast, in 2011 there was little or no soil moisture replenishment after planting, and elevating temperature exacerbated this effect in the upper soil, which was at or near the wilting point (ca. 21\% VWC) for most July and August (Fig. 1). Also unlike 2009, VWC profiles were similar between treatments in 2011 suggesting that plants in HOT plots may not have had access to additional moisture compared to CON plots in 2011, which is consistent with a greater temperature effect on plant water potential in HOT plots in 2011 compared to 2009 [27]. Thus, the low soil moisture in 2011, when combined with the detrimental effect of higher ambient temperatures and greater vapor pressure deficits [27], exacerbated the effects of chronic temperature elevation and likely contributed to the substantial decreases in yield reported for HOT plots in 2011.

As seen in numerous previous field and enclosure studies $[10,21]$, soybean acclimated to growth at elevated $\left[\mathrm{CO}_{2}\right]$ by lowering in vivo carboxylation capacity $\left(V_{c, \max @ 25}\right)$ and elevating $\left[\mathrm{CO}_{2}\right]$ had a smaller effect on $J_{\max @ 25}$ (Fig. 1). Additionally, assimilation rates of plants in 585 plots were lower than those of plants in 385 plots when compared at a common ambient $\left[\mathrm{CO}_{2}\right]$ of $385 \mathrm{ppm}$ (i.e. $A_{@ 385 p p m}$ ), consistent with downregulation of $V_{c, \max }$ at elevated $\mathrm{CO}_{2}$ [10]. The decrease in $V_{c, \max @ 25}$ at elevated $\mathrm{CO}_{2}$ is likely due to decreases in Rubisco amount or activation state [3]. However, regardless of lower $V_{c, \text { max } @ 25}, N_{\text {mass }}$ and $N_{\text {area }}$, light saturated photosynthesis measured at growth $\left[\mathrm{CO}_{2}\right]\left(A_{@ g r o w t h}\right)$ remained higher in elevated $\mathrm{CO}_{2}$ plots (Fig. 2) [27], consequently, photosynthetic nitrogen use efficiency remained higher at elevated $\left[\mathrm{CO}_{2}\right]$ (Supplemental Figure 3) [40].

Acclimation of $V_{c, \text { max }}$ and $J_{\max }$ to combined increases in $\left[\mathrm{CO}_{2}\right]$ and temperature varies substantially across species and experiments $[3,41-43]$. Moderately elevated temperature alone (i.e. $+4{ }^{\circ} \mathrm{C}$ ) has been reported to either increase [43,44], decrease [3,6,43] or not change $V_{c, \max }$ [43]. At $\left[\mathrm{CO}_{2}\right]$ of ca. $350 \mathrm{ppm}$ moderate increases in temperature may have little effect on $V_{c, \max }$ as long as growth temperatures remain below the photosynthetic optimum; when growth temperatures consistently exceed the temperature optimum of $A, V_{c, \max }$ down-regulates significantly [3,6]. On average, $J_{\max }$ acclimates more than $V_{c, \max }$ at higher growth temperatures [44-46] and less than $V_{c, \max }$ at elevated $\mathrm{CO}_{2}$. Here, $V_{c, \max @ 25}$ did not detectably change in response to elevated temperature when averaged for the entire season in either year suggesting that plant canopy temperatures did not exceed the temperature optimum of $A$. Moreover, $V_{c, \max @ 25}$ did not acclimate more to elevated $\left[\mathrm{CO}_{2}\right]$ in the dryer, hotter, 2011 season which is consistent with nodulated alfalfa where down regulation of $V_{c, \max }$ at elevated $\left[\mathrm{CO}_{2}\right]$ occurred irrespective of temperature and drought [47]. In contrast, nonleguminous species including red maple [48], black spruce [49], wheat [6] and spinach [50] report decreases in $V_{c, \max 25}$ in plants grown at moderately elevated daytime temperatures (i.e. $+3.5^{\circ} \mathrm{C}$ to $\left.+6^{\circ} \mathrm{C}\right)$.

Seasonal increases and subsequent declines in leaf $\mathrm{N}$, which were more clearly seen in 2009, are typical for soybean [51],

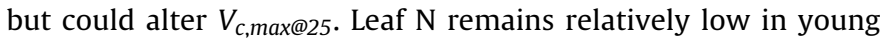
soybeans, because of a lag between nodule formation just after emergence and active $\mathrm{N}$ fixation, after which leaf $\mathrm{N}$ increases rapidly to a peak level [52]. Subsequent declines in leaf $\mathrm{N}$ following pod formation in soybeans are due to senecence as leaf $\mathrm{N}$ is retranslocated to developing pods [36,52]. Because of the dependence of leaf assimilation and biochemistry on leaf $\mathrm{N}$ we also assessed trait responses to treatments prior to senescence. In the latter analysis, we see that $V_{c, \max @ 25}$ was greater in HOT compared to CON plots prior to senescence consistent with higher $N_{\text {mass }}$ and $N_{\text {area }}$ during the same period of 2009. Increased access to moisture in 2009 and warmer temperature in the HOT plots would likely increase the nitrogen nutrition of plants whereas nitrogen nutrition in soybeans was inhibited in drought [53] potentially explaining why $N_{\text {area }}$ was higher in HOT plots compared to control plots in 2009 and why in $2011 \mathrm{~N}$ levels were generally lower than at comparable developmental stages in 2009. Thus, when leaf $\mathrm{N}$ was higher in HOT plots and in the absence of water stress, elevated temperature and $\left[\mathrm{CO}_{2}\right]$ increased carboxylation capacity relative to elevated $\left[\mathrm{CO}_{2}\right]$ alone which is consistent with a recent metaanalysis of plant responses to elevated $\left[\mathrm{CO}_{2}\right]$ and temperature [7] and mirrors nodulating Medicago trunculata grown in temperature gradient tunnels $\left(+4{ }^{\circ} \mathrm{C}\right)$ at ambient and elevated $(700 \mathrm{ppm}) \mathrm{CO}_{2}$ [54].

Significantly lower $J_{\max @ 25}$ (Fig. 2) when coupled with lower operating efficiency of photosystem II $\left(\Phi_{\text {PSII }}\right)$ (Supplemental Figure 1 ) are indicative of a cumulative effect of acclimation to temperature and adjustments in energy partitioning in PSII [55] or possibly temperature induced damage to photosystem II because these decreases were observed in predawn collected leaves measured under similar temperatures and relative humidity. Such damage or changes in energy partitioning in photosystem II directly reduce $A$ 


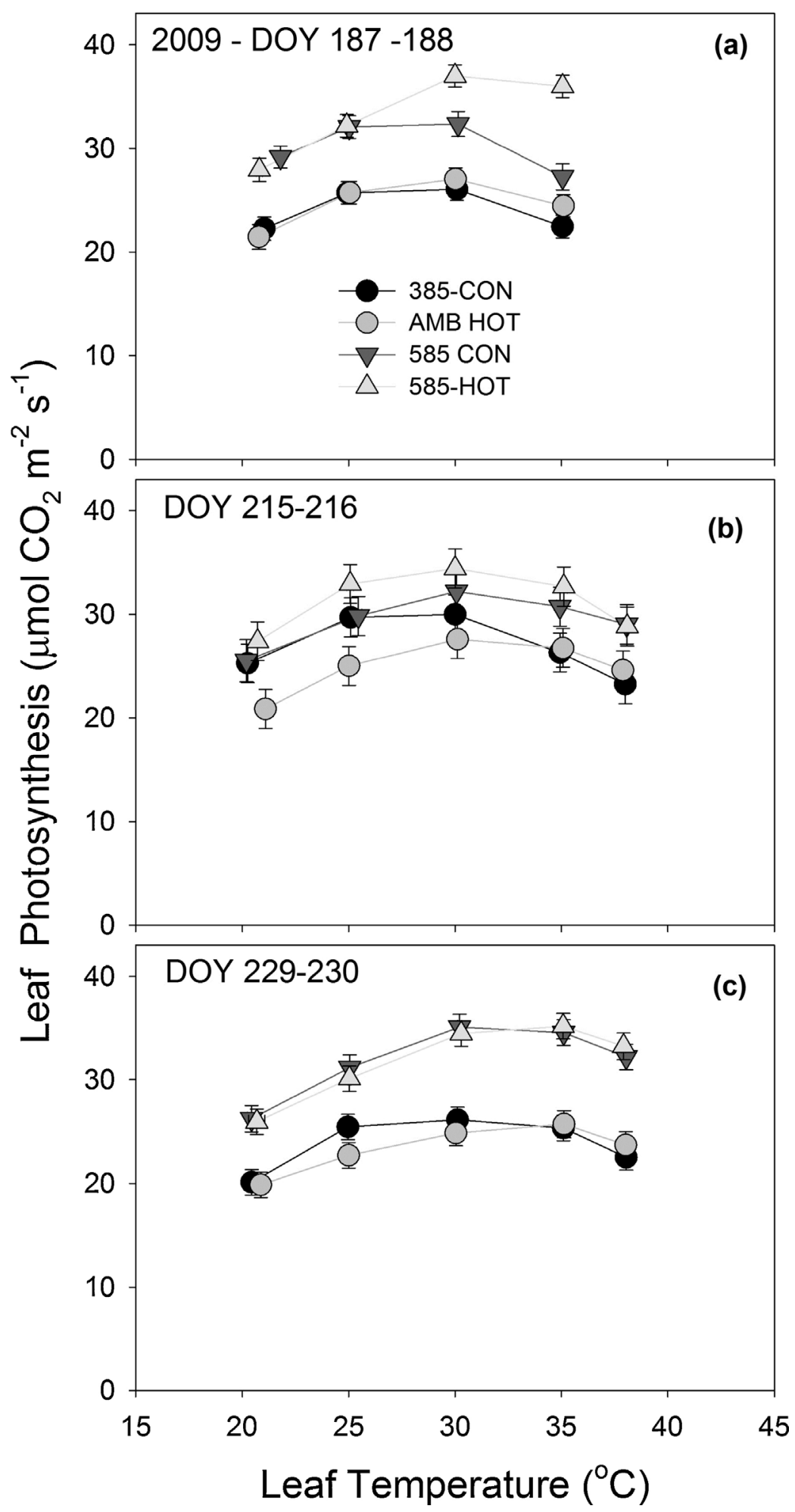

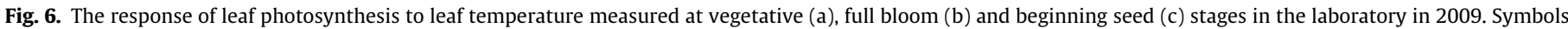

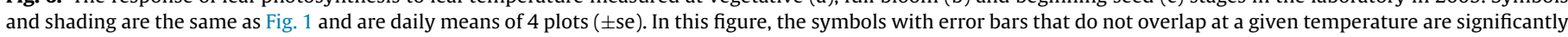
different $(p<0.05)$.

[56] and could lead to a lower realized benefit of elevated $\left[\mathrm{CO}_{2}\right]$ when coupled with increases in temperature. Indeed, $A$ becomes increasingly RuBP limited at elevated $\left[\mathrm{CO}_{2}\right]$ and the decreases in $J_{\max }$ reported here directly contributed to decreases in RuBP limited carbon assimilation and likely lower yields of soybean in the field [27]. Thus future increases in temperature will likely have a proportionally larger effect on carbon gain and future yields.
Stomatal limitation of $A$ decreases with increasing $\mathrm{CO}_{2}$ because of the non-linear response of $A$ to $C_{i}$ [23]; consequently in spite of a 25 and $31 \%$ decrease in $g_{s}$ in 585-CON compared to 385-CON plots in 2009 and 2011, respectively [27], stomatal limitation in the field $\left(l_{-}\right.$field $)$was $14 \%$ less in elevated $\left[\mathrm{CO}_{2}\right]$ plots when compared to controls in both years, which is within the same range previously reported for soybean grown at SoyFACE [19]. Elevated temperature, 
independent of $\left[\mathrm{CO}_{2}\right]$, also decreased $g_{s}$ and $C_{i}$ in the field [27] consistent with greater $l_{\text {field }}$ in HOT plots (Fig. 4). However, the combination of elevated temperature and $\mathrm{CO}_{2}$ increased $l_{\text {field }}$ by $20-27 \%$ compared to $385-C O N$ in 2009 and 2011, respectively. Thus, while elevated $\mathrm{CO}_{2}$ decreased stomatal limitation of $A$ as expected, elevated temperature eliminated the benefit of elevated $\left[\mathrm{CO}_{2}\right]$ on the physical limitation of $A$ in both years.

The measured responses of $A$ to temperature conformed to theoretical expectations with respect to elevated $\mathrm{CO}_{2}[13,17]$ but the synergistic effect of increasing $\left[\mathrm{CO}_{2}\right]$ and temperature on the thermal response of $A$ was absent later in the season, at least in 2009. For instance, while $A$ was higher at all measurement temperatures in elevated $\left[\mathrm{CO}_{2}\right]$ (e.g. Sage et al. [57]), $A$ was significantly higher in the 585 -HOT plots when compared to 585-CON plots, but only in July of 2009. This stimulation of the temperature response of $A_{@ g r o w t h}$ occurred when leaf N levels were higher in HOT plots and when soil moisture was identical and near field capacity in all plots, following a large $(37 \mathrm{~mm}$ ) precipitation event in 2009 . Thus, it appears that theoretical expectations of the thermal response of $A$ are met in the field but possibly only under near optimal conditions.

There has been much discussion about the theoretical modification of the temperature response of leaf photosynthesis at elevated $\left[\mathrm{CO}_{2}\right]$ since the seminal review by Long [13]. While the latter theoretical analysis accounted for the acclimation of $V_{c, \max }$ to elevated $\left[\mathrm{CO}_{2}\right]$, the study by Long [13] did not have sufficient data to support the notion of acclimation of $V_{c, \max }$ or $J_{\max }$ to temperature and its effect on the modification of the temperature response of $A$ at elevated $\left[\mathrm{CO}_{2}\right]$. Here, the combined acclimation of $V_{c, \max @ 25}$ and $J_{\max @ 25}$ and the shift in $V_{c, \max @ 25} / J_{\max @ 25}$ are consistent with a shift toward RuBP regeneration limited photosynthesis at elevated $\left[\mathrm{CO}_{2}\right]$ (e.g. $\left.[1,13,19]\right)$; therefore, the benefit of elevated $\left[\mathrm{CO}_{2}\right]$ on the temperature response of $A$ may also decrease because acclimation of $J_{\max } @ 25$ to elevated temperature can lower RuBP regeneration limited $A$. Thus, while the temperature response of $A$ is almost always enhanced at elevated $\left[\mathrm{CO}_{2}\right][8,17,19]$ and the realized benefit of elevated $\left[\mathrm{CO}_{2}\right]$ increases with temperature $[37,41]$ longer term growth at elevated $\left[\mathrm{CO}_{2}\right]$ and elevated temperature can be less than additive with respect to $A$ as seen here and in some other enclosure studies [6,58].

\section{Concluding remarks}

Improving crop productivity within the context of climate change remains a critical goal if we are to meet global food demands $[39,59,60]$. While photosynthetic responses to climate change differ among species and genotypes [48,50,61-64] the greater than expected acclimation of key photosynthetic processes reported here has important implications for $C_{3}$ photosynthesis beyond that of soybeans. Indeed, assessing the magnitude and direction of acclimation is crucial to our understanding of global carbon flux and food security because $A$ modulates the largest exchange of carbon from the atmosphere into ecosystems and is an important determinant of crop yields. Finally, and perhaps most importantly, photosynthetic acclimation to temperature and $\mathrm{CO}_{2}$ when combined under field conditions may be greater than reported in some enclosure studies (cf. Long et al. [65]) and will modify regional variation in $\mathrm{CO}_{2}$ stimulation reported in [66].

\section{Acknowledgments}

We gratefully acknowledge the dedication of David Drag to ensuring the successful operation of T-FACE. We also acknowledge both Kannan Puthuval and David Drag for managing the overall SoyFACE site. We thank John Spiekerman, Stephanie Klein, Natalia
Ordonez, and Becky Slattery for helping with gas exchange measurements. Funding for this research was provided by the United States Department of Agriculture (USDA) Agriculture Research Service (ARS) and by the Office of Science (BER), US Department of Energy, through the Midwestern Center of the National Institute for Climate Change Research (NICCR).

\section{Appendix A. Supplementary data}

Supplementary data associated with this article can be found, in the online version, at http://dx.doi.org/10.1016/j.plantsci. 2014.06.013.

\section{References}

[1] S.P. Long, E.A. Ainsworth, A. Rogers, D.R. Ort, Rising atmospheric carbon dioxide: plants face the future, Annu. Rev. Plant Biol. 55 (2004) 591-628.

[2] IPCC, Summary for policy makers, in: S. Solomon, D. Quin, M. Manning, Z. Chen, M. Marquis, K.B. Averyt, M. Tignor, H.L. Miller (Eds.), Climate Change 2007: The Physical Science Basis. Contribution of Working Group 1 to the Fourth Assessment Report of the Intergovernmental Panel on Climate Change, Cambridge University Press, Cambridge, UK and New York, NY, 2007.

[3] J.C.V. Vu, L.H. Allen, K.J. Boote, G. Bowes, Effects of elevated $\mathrm{CO}_{2}$ and temperature on photosynthesis and Rubisco in rice and soybean, Plant Cell Environ. 20 (1997) 68-76.

[4] L.H. Ziska, J.A. Bunce, Growth and photosynthetic response of 3 soybean cultivars to simultaneous increases in growth temperature and $\mathrm{CO}_{2}$, Physiol. Plant 94 (1995) 575-584

[5] S. Kellomaki, K.Y. Wang, Effects of long-term $\mathrm{CO}_{2}$ and temperature elevation on crown nitrogen distribution and daily photosynthetic performance of Scots pine, Forest Ecol. Manage. 99 (1997) 309-326.

[6] A. Alonso, P. Perez, R. Morcuende, R. Martinez-Carrasco, Future $\mathrm{CO}_{2}$ concentrations, though not warmer temperatures, enhance wheat photosynthesis temperature responses, Physiol. Plant. 132 (2008) 102-112.

[7] D. Wang, S.A. Heckathorn, X. Wang, S.M. Philpott, A meta-analysis of plant physiological and growth responses to temperature and elevated $\mathrm{CO}_{2}$, Oecologia 169 (2012) 1-13.

[8] S. von Caemmerer, Biochemical Models of Leaf Photosynthesis, CSIRO Publishing, Collingwood, Victoria, Australia, 2000.

[9] C.J. Bernacchi, J.E. Bagley, S.P. Serbin, U.M. Ruiz-Vera, D.M. Rosenthal, A. Vanloocke, Modelling $C_{3}$ photosynthesis from the chloroplast to the ecosystem, Plant Cell Environ. 36 (2013) 1641-1657.

[10] A. Rogers, S.W. Humphries, A mechanistic evaluation of photosynthetic acclimation at elevated $\mathrm{CO}_{2}$, Global Change Biol. 6 (2000) 1005-1011.

[11] T.J. Conway, P. Tans, Trends in atmospheric $\mathrm{CO}_{2}$, NOAA Earth Systems Research Laboratory, 2012. http://www.esrl.noaa.gov/gmd/ccgg/trends/

[12] D.B. Jordan, W.L. Ogren, The $\mathrm{CO}_{2} / \mathrm{O}_{2}$ specificity of ribulose 1,5-bisphosphate carboxylase/oxygenase: dependence on ribulosebisphosphate concentration, pH and temperature, Planta 161 (1984) 308-313.

[13] S.P. Long, Modification of the response of photosynthetic productivity to rising temperature by atmospheric $\mathrm{CO}_{2}$ concentrations - has its importance been underestimated? Plant Cell Environ. 14 (1991) 729-739.

[14] E.A. Ainsworth, A. Rogers, The response of photosynthesis and stomatal conductance to rising $\left[\mathrm{CO}_{2}\right]$ : mechanisms and environmental interactions, Plant Cell Environ. 30 (2007) 258-270.

[15] P.S. Curtis, X. Wang, A meta-analysis of elevated $\mathrm{CO}_{2}$ effects on woody plant mass, form, and physiology, Oecologia 113 (1998) 299-313.

[16] R.S. Nowak, D.S. Ellsworth, S.D. Smith, Functional responses of plants to elevated atmospheric $\mathrm{CO}_{2}$ - do photosynthetic and productivity data from FACE experiments support early predictions? New Phytol. 162 (2004) 253-280.

[17] R.F. Sage, D.S. Kubien, The temperature response of C-3 and C-4 photosynthesis, Plant Cell Environ. 30 (2007) 1086-1106.

[18] A.D.B. Leakey, E.A. Ainsworth, C.J. Bernacchi, A. Rogers, S.P. Long, D.R. Ort, Elevated $\mathrm{CO}_{2}$ effects on plant carbon, nitrogen, and water relations: six important lessons from FACE, J. Exp. Bot. 60 (2009) 2859-2876.

[19] C.J. Bernacchi, P.B. Morgan, D.R. Ort, S.P. Long, The growth of soybean under free air $\mathrm{CO}_{2}$ enrichment (FACE) stimulates photosynthesis while decreasing in vivo Rubisco capacity, Planta 220 (2005) 434-446.

[20] D.M. Rosenthal, A.M. Locke, M. Khozaei, C.A. Raines, S.P. Long, D.R. Ort Over-expressing the $C_{3}$ photosynthesis cycle enzyme sedoheptulose-1,7bisphosphatase improves photosynthetic carbon gain and yield under fully open air $\mathrm{CO}_{2}$ fumigation (FACE), BMC Plant Biol. (2011), http://dx.doi.org/ 10.1186/1471-2229-11-123.

[21] E.A. Ainsworth, S.P. Long, What have we learned from 15 years of Free-Air $\mathrm{CO}_{2}$ Enrichment(FACE)? A meta-analytic review of the responses of photosynthesis, canopy properties and plant production to rising $\mathrm{CO}_{2}$, New Phytol. 165 (2005) $351-371$

[22] W.L. Bauerle, J.D. Bowden, G.G. Wang, The influence of temperature on withincanopy acclimation and variation in leaf photosynthesis: spatial acclimation to microclimate gradients among climatically divergent Acer rubrum L. genotypes, J. Exp. Bot. 58 (2007) 3285-3298 
[23] G.D. Farquhar, T.D. Sharkey, Stomatal conductance and photosynthesis, Annu. Rev. Plant Physiol. Plant Mol. Biol. 33 (1982) 317-345.

[24] USDA, National Agricultural Statistics Service, 2013. http://www.nass.usda. gov/Statistics_by_Subject/index.asp

[25] B.A. Kimball, Theory and performance of an infrared heater for ecosystem warming, Global Change Biol. 11 (2005) 2041-2056.

[26] B.A. Kimball, M.M. Conley, S. Wang, X. Lin, C. Luo, J. Morgan, D. Smith, Infrared heater arrays for warming ecosystem field plots, Global Change Biol. 14 (2008) 309-320.

[27] U.M. Ruiz-Vera, M. Siebers, S.B. Gray, D.W. Drag, D.M. Rosenthal, B.A. Kimball, D.R. Ort, C.J. Bernacchi, Global warming can negate the expected $\mathrm{CO}_{2}$ stimulation in photosynthesis and productivity for soybean grown in the midwestern United States, Plant Physiol. 162 (2013) 410-423.

[28] P.B. Morgan, G.A. Bollero, R.L. Nelson, F.G. Dohleman, S.P. Long, Smaller than predicted increase in aboveground net primary production and yield of fieldgrown soybean under fully open-air $\left[\mathrm{CO}_{2}\right]$ elevation, Global Change Biol. 11 (2005) 1856-1865.

[29] D.R. Ort, E.A. Ainsworth, M. Aldea, D.J. Allen, C.J. Bernacchi, G.A. Berenbaum, G.A Bollero, G. Cornic, P.A. Davey, O. Dermody, F.G. Dohleman, J.G. Hamilton, E.A. Heaton, A.D.B. Leakey, J. Mahoney, T.A. Mies, P.B. Morgan, R. Nelson, B. O'Neil, A. Rogers, A.R. Zangerl, X.G. Zhu, E.H. DeLucia, S.P. Long, SoyFACE: the effects and interactions of elevated $\left[\mathrm{CO}_{2}\right]$ and $\left[\mathrm{O}_{3}\right]$ on soybeans, in: J. Nosberger, S.P. Long, R.J. Norby, M. Stitt, G.R. Hendry, H. Blum (Eds.), Managed Ecosystems and $\mathrm{CO}_{2}$, Springer, Berlin, 2006, pp. 71-86.

[30] P.B. Morgan, C.J. Bernacchi, D.R. Ort, S.P. Long, An in vivo analysis of the effect of season-long open-air elevation of ozone to anticipated 2050 levels on photosynthesis in soybean, Plant Physiol. 135 (2004) 2348-2357.

[31] G.D. Farquhar, E.D. Schulze, M. Kuppers, Responses to humidity by stomata of Nicotiana glauca L. and Corylus avellana L. are consistent with the optimization of carbon uptake with respect to water loss, Aust. J. Plant Physiol. 7 (1980) 315-327.

[32] S.P. Long, C.J. Bernacchi, Gas exchange measurements, what can they tell us about the underlying limitations to photosynthesis? Procedures and sources of error, J. Exp. Bot. 54 (2003) 2393-2401.

[33] G.D. Farquhar, S. von Caemmerer, J.A. Berry, A biochemical model of photosynthetic $\mathrm{CO}_{2}$ assimilation in leaves of $C_{3}$ species, Planta 149 (1980) 78-90.

[34] S.M. Scheiner, Theories hypotheses and statistics, in: S.M. Scheiner, J. Gurevitch (Eds.), Design and Analysis of Ecological Experiments, Oxford University Press, New York, 2001, pp. 3-13.

[35] R.R. Sokal, F.J. Rohlf, Estimation and hypothesis testing, in: Biometry, W.H. Freeman, New York, 1995, pp. 127-175.

[36] L.D. Nooden, J.J. Guiamet, I. John, Senescence mechanisms, Physiol. Plant. 101 (1997) 746-753.

[37] C.J. Bernacchi, A.D.B. Leakey, L.E. Heady, P.B. Morgan, F.G. Dohleman, J.M. McGrath, K.M. Gillespie, V.E. Wittig, A. Rogers, S.P. Long, D.R. Ort, Hourly and seasonal variation in photosynthesis and stomatal conductance of soybean grown at future $\mathrm{CO}_{2}$ and ozone concentrations for 3 years under fully open-air field conditions, Plant Cell Environ. 29 (2006) 2077-2090.

[38] S.P. Long, B.G. Drake, Effect of the long term elevation of $\mathrm{CO}_{2}$ concentration in the field on the quantum yield of photosynthesis of the C3 sedge, Scirpus olneyi, Plant Physiol. 96 (1991) 221-226.

[39] S.P. Long, D.R. Ort, More than taking the heat: crops and global change, Curr. Opin. Plant Biol. 13 (2010) 241-248.

[40] B.G. Drake, M.A. Gonzalez-Meler, S.P. Long, More efficient plants: a consequence of rising atmospheric $\mathrm{CO}_{2}$ ? Annu. Rev. Plant Physiol. Plant Mol. Biol. 48 (1997) 609-639.

[41] A. Alonso, P.A. Perez, R. Martinez-Carrasco, Growth in elevated $\mathrm{CO}_{2}$ enhances temperature response of photosynthesis in wheat, Physiol. Plant. 135 (2009) 109-120.

[42] A. Borjigidai, K. Hikosaka, T. Hirose, T. Hasegawa, M. Okada, K. Kobayashi, Seasonal changes in temperature dependence of photosynthetic rate in rice under a free-air $\mathrm{CO}_{2}$ enrichment, Ann. Bot. 97 (2006) 549-557.

[43] C.M. Stirling, P.A. Davey, T.G. Williams, S.P. Long, Acclimation of photosynthesis to elevated $\mathrm{CO}_{2}$ and temperature in five British native species of contrasting functional type, Global Change Biol. 3 (1997) 237-246.

[44] J.D. Lewis, M. Lucash, D.M. Olszyk, D.T. Tingey, Relationships between needle nitrogen concentration and photosynthetic responses of Douglas-fir seedlings to elevated $\mathrm{CO}_{2}$ and temperature, New Phytol. 162 (2004) 355-364.
[45] C.J. Bernacchi, C. Pimentel, S.P. Long, In vivo temperature response functions of parameters required to model RuBP-limited photosynthesis, Plant Cell Environ. 26 (2003) 1419-1430,

[46] D.A. Way, R.F. Sage, Thermal acclimation of photosynthesis in black spruce [Picea mariana (Mill.) BSP], Plant Cell Environ. 31 (2008) 1250-1262.

[47] I. Aranjuelo, P. Perez, L. Hernandez, J.J. Irigoyen, G. Zita, R. Martinez-Carrasco, M Sanchez-Diaz, The response of nodulated alfalfa to water supply, temperature and elevated $\mathrm{CO}_{2}$ : photosynthetic downregulation, Physiol. Plant. 123 (2005) 348-358.

[48] D.J. Weston, W.L. Bauerle, Inhibition and acclimation of C-3 photosynthesis to moderate heat: a perspective from thermally contrasting genotypes of Acer rubrum (red maple), Tree Physiol. 27 (2007) 1083-1092.

[49] D.A. Way, R.F. Sage, Elevated growth temperatures reduce the carbon gain of black spruce Picea mariana (Mill.) BSP, Global Change Biol. 14 (2008) 624-636.

[50] W. Yamori, K. Noguchi, I. Terashima, Temperature acclimation of photosynthesis in spinach leaves: analyses of photosynthetic components and temperature dependencies of photosynthetic partial reactions, Plant Cell Environ. 28 (2005) 536-547.

[51] O. Dermody, S.P. Long, E.H. DeLucia, How does elevated $\mathrm{CO}_{2}$ or ozone affect the leaf-area index of soybean when applied independently? New Phytol. 169 (2006) 145-155.

[52] A. Rogers, Y. Gibon, M. Stitt, P.B. Morgan, C.J. Bernacchi, D.R. Ort, S.P. Long, Increased C availability at elevated carbon dioxide concentration improves N assimilation in a legume, Plant Cell Environ. 29 (2006) 1651 1658.

[53] S.B. Gray, R.S. Strellner, K.K. Puthuval, C. Ng, R.E. Shulman, M.H. Siebers, A. Rogers, A.D.B. Leakey, Minirhizotron imaging reveals that nodulation of fieldgrown soybean is enhanced by free-air $\mathrm{CO}_{2}$ enrichment only when combined with drought stress, Funct. Plant Biol. 40 (2013) 137-147.

[54] I. Aranjuelo, J.J. Irigoyen, M. Sanchez-Diaz, S. Nogues, Carbon partitioning in $\mathrm{N}_{2}$ fixing Medicago sativa plants exposed to different $\left[\mathrm{CO}_{2}\right]$ and temperature conditions, Funct. Plant Biol. 35 (2008) 306-317.

[55] B.A. Logan, C.R. Hricko, J.D. Lewis, O. Ghannoum, N.G. Phillips, R. Smith, J.P. Conroy, D.T. Tissue, Examination of pre-industrial and future $\mathrm{CO}_{2}$ reveals the temperature-dependent $\mathrm{CO}_{2}$ sensitivity of light energy partitioning at PSII in eucalypts, Funct. Plant Biol. 37 (2010) 1041-1049.

[56] N.R. Baker, Chlorophyll fluorescence: a probe of photosynthesis in vivo, Annu. Rev. Plant Biol. 59 (2008) 89-113.

[57] R.F. Sage, J. Santrucek, D.J. Grise, Temperature effects on the photosynthetic response of $\mathrm{C}-3$ plants to long-term $\mathrm{CO}_{2}$ enrichment, Vegetatio 121 (1995) $67-77$.

[58] L.H. Ziska, J.A. Bunce, Increasing growth temperature reduces the stimulatory effect of elevated $\mathrm{CO}_{2}$ on photosynthesis or biomass in 2 perennial species, Physiol. Plant. 91 (1994) 183-190.

[59] D. Tilman, C. Balzer, J. Hill, B.L. Befort, Global food demand and the sustainable intensification of agriculture, Proc. Natl. Acad. Sci. U.S.A. 108 (2011) 20260-20264.

[60] X.G. Zhu, S.P. Long, D.R. Ort, Improving photosynthetic efficiency for greater yield, Annu. Rev. Plant Biol. 61 (2010) 235-261.

[61] J.A. Bunce, Acclimation of photosynthesis to temperature in eight cool and warm climate herbaceous C-3 species: temperature dependence of parameters of a biochemical photosynthesis model, Photosynth. Res. 63 (2000) 59-67.

[62] J. Kattge, W. Knorr, Temperature acclimation in a biochemical model of photosynthesis: a reanalysis of data from 36 species, Plant Cell Environ. 30 (2007) 1176-1190.

[63] L.H. Ziska, Growth temperature can alter the temperature dependent stimulation of photosynthesis by elevated carbon dioxide in Albutilon theophrasti, Physiol. Plant. 111 (2001) 322-328.

[64] W. Yamori, K. Noguchi, K. Hikosaka, I. Terashima, Phenotypic plasticity in photosynthetic temperature acclimation among crop species with different cold tolerances, Plant Physiol. 152 (2010) 388-399.

[65] S.P. Long, E.A. Ainsworth, A.D.B. Leakey, J. Nosberger, D.R. Ort, Food for thought: lower-than-expected crop yield stimulation with rising $\mathrm{CO}_{2}$ concentrations, Science 312 (2006) 1918-1921.

[66] J.M. McGrath, D.B. Lobell, Regional disparities in the $\mathrm{CO}_{2}$ fertilization effect and implications for crop yields, Environ. Res. Let. 8 (2013) 014054. 
Supplemental material for the manuscript titled:

Biochemical acclimation, stomatal limitation and precipitation patterns underlie decreases in photosynthetic stimulation of soybean (Glycine max) at elevated $\left[\mathrm{CO}_{2}\right]$ and temperatures under fully open air field conditions

David M. Rosenthal ${ }^{1,2}$, Ursula M. Ruiz-Vera ${ }^{3}$, Matthew H. Siebers ${ }^{3}$, Sharon B. Gray, Carl J. Bernacchi $^{1,3,4}$, Donald R. Ort ${ }^{1,3,4}$

${ }^{1}$ Global Change and Photosynthesis Research Unit, USDA Agricultural Research Service, Urbana, IL 61801 USA

${ }^{2}$ Current address: Ohio University, Department of Environmental and Plant Biology, Athens Ohio, 45701.

${ }^{3}$ Department of Plant Biology, University of Illinois at Urbana-Champaign, Urbana, IL 61801, USA

${ }^{4}$ Institute for Genomic Biology, University of Illinois at Urbana-Champaign, Urbana, IL 61801, USA

Author for correspondence d-ort@illinois.edu; +(217) 333-2093 
Supplemental Figure 1. Operating efficiency of photosystem II ( $\Phi$ PSII) for leaves collected at dawn. Where $\Phi P S I I=\frac{F m^{\prime}-F s^{\prime}}{F m^{\prime}}$ and Fs' is steady state (i.e. light adapted) fluorescence and Fm' is maximal fluorescence during a saturating pulse of light [1] . Data were collected during A vs. Ci curves on six dates in 2009 and 2011. See main paper for details. Mean response of $\Phi$ PSII to the effects of elevated $\mathrm{CO}_{2}$ and elevated temperature, singly and in combination, in 2009 and 2011. Bars represent the means of 4 plots on 6 days in 2009 and 6 days in 2011. Within years, bars with different letters are significantly different $(\mathrm{p}<0.05)$.

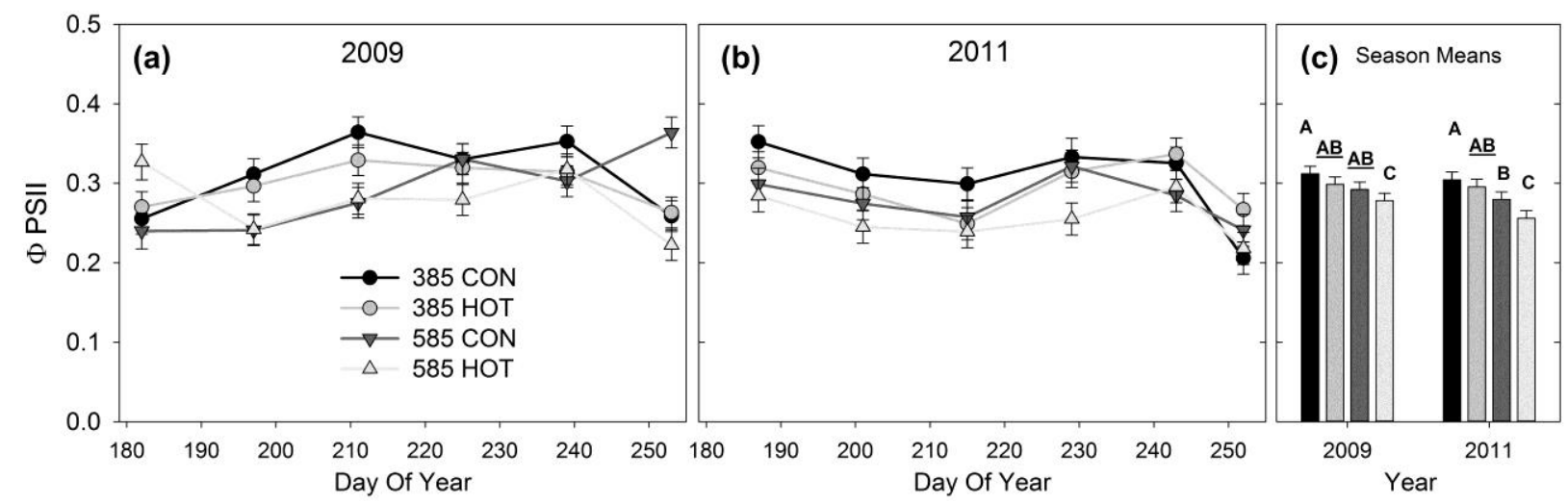

Supplemental table 1. Results of the repeated measure ANOVA of the effect of day of year (DOY), elevated $\mathrm{CO}_{2}$, elevated Temperature, and their interaction on the operating efficiency of photosystem II ( PPSII) for each of the two years $(2009,2011)$.

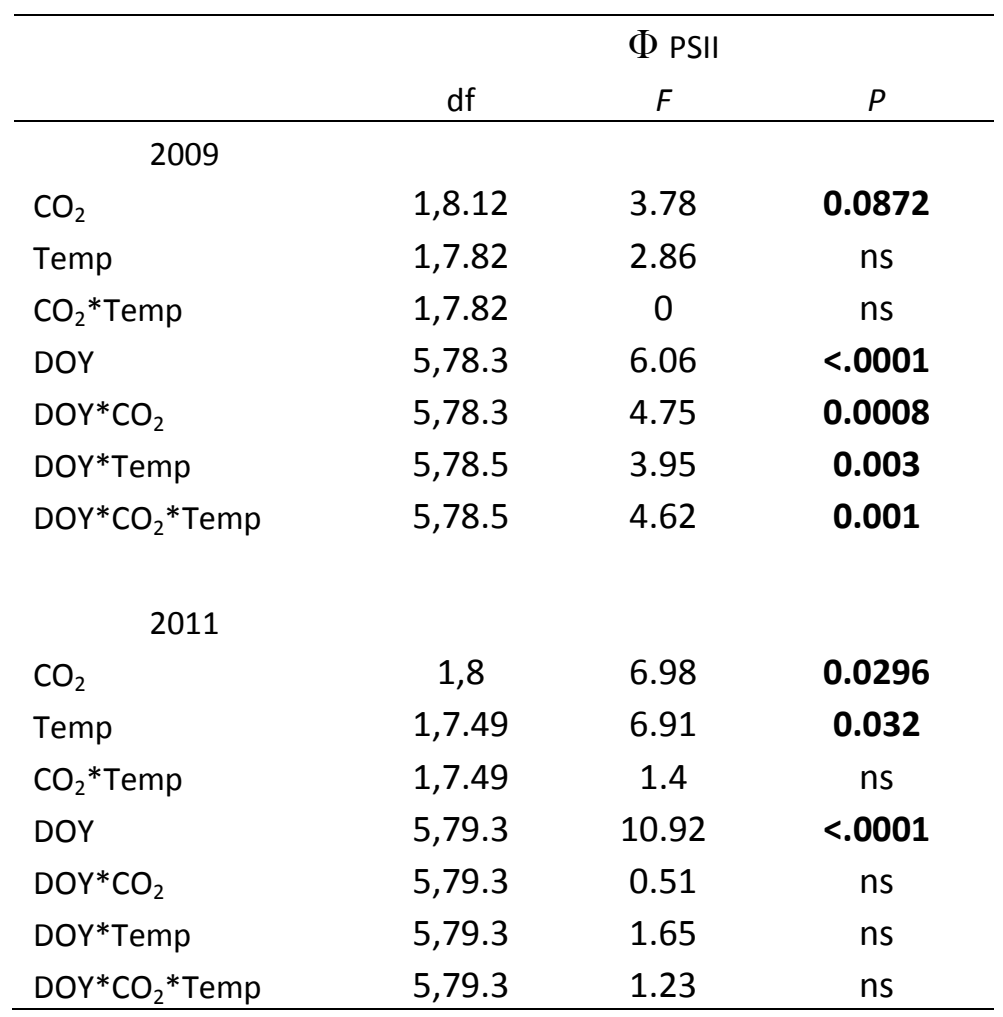


Supplemental Figure 2. Seasonal variation in 2009 (left), in 2011 (center), and annual means (right) of stomatal conductance $\left(\mathrm{g}_{\mathrm{s}}\right)$ and the ratio of sub-stomatal to atmospheric $\mathrm{CO}_{2}$ (cica) measured at growth $\mathrm{CO}_{2}$ measured on leaves collected predawn in the field and measured in the lab for control (385-CON), elevated $\mathrm{CO}_{2}(585-\mathrm{CON})$, elevated temperature (385-HOT) and the combined treatment (585-HOT). Round symbols are daily means of 4 plots $( \pm$ se). Overall means $( \pm$ se) are for 7 days in 2009 and 6 days in 2011. Within years, bars with different letters in panels (f) and (i) are significantly different ( $\mathrm{p}<0.05)$.

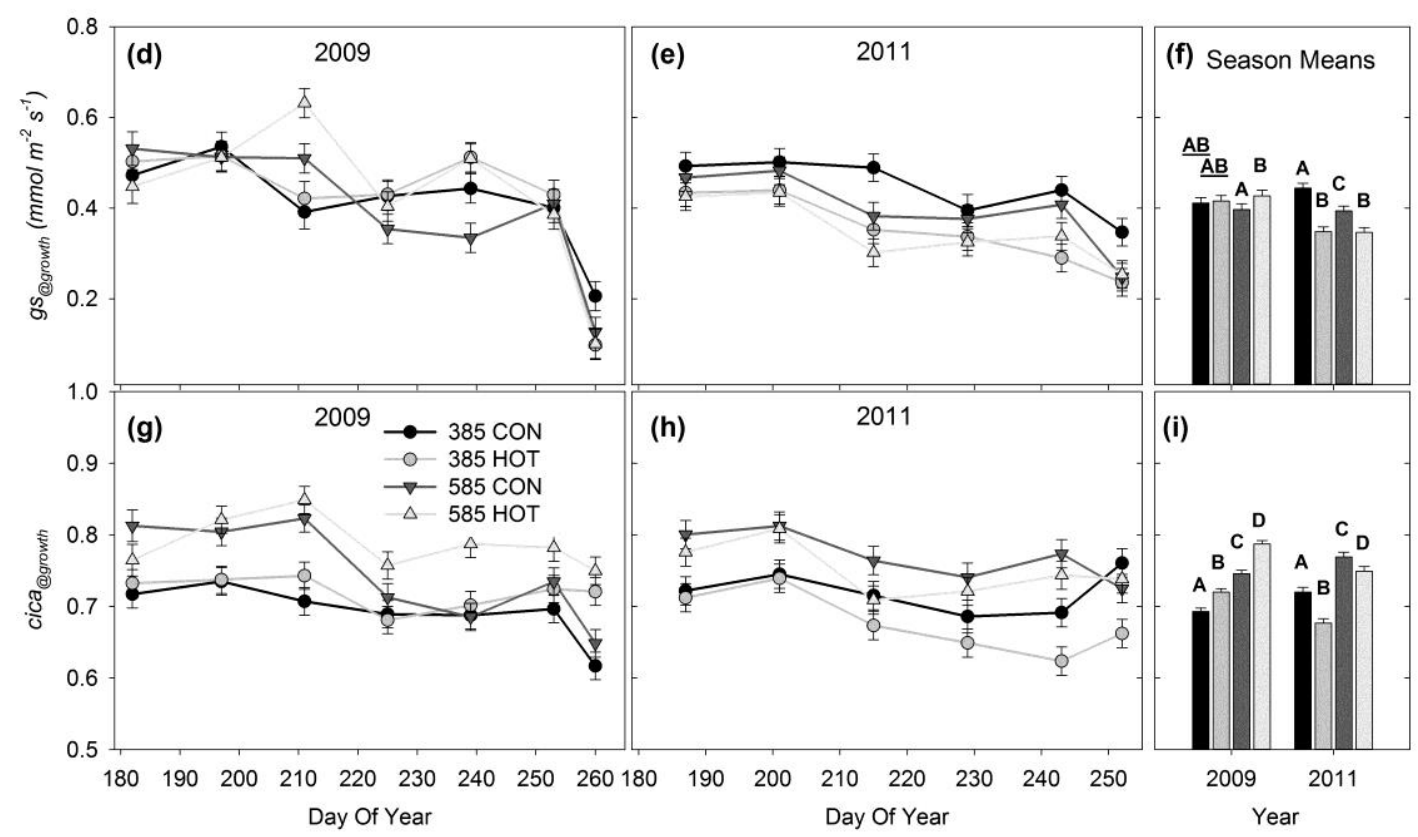


Supplemental Figure 3. Seasonal variation of photosynthetic nitrogen use efficiency (PNUE) in 2009 (left), in 2011 (center), and annual means (right) in control (385-CON), elevated $\mathrm{CO}_{2}(585$ $\mathrm{CON}$ ), elevated temperature (385-HOT) and the combined treatment (585-HOT). Round symbols are daily means of 4 plots $( \pm$ se). Overall means ( \pm se) are for 6 days in 2009 and 5 days in 2011. Within years bars with different letters are significantly different (as there were only four blocks, significant probability was set a priori at $p<0.1$ to reduce the likelihood of type II errors). PNUE was calculated using plot means of photosynthesis measured around midday and plot means of $N_{\text {area }}$ data reported in the text.

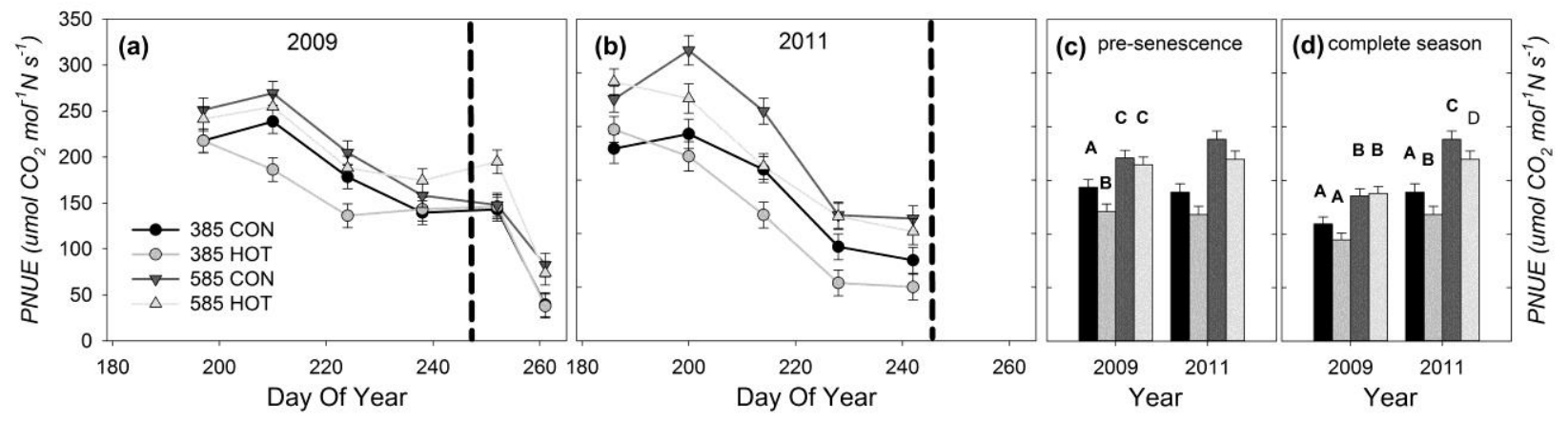


References cited

[1] N.R. Baker, Chlorophyll fluorescence: A probe of photosynthesis in vivo, Annual Review of Plant Biology, 59 (2008) 89-113. 